\title{
Any Signs of Green Growth? A Spatial Panel Analysis of Regional Air Pollution in South Korea
}

\author{
Erik Hille $^{1} \cdot$ Bernhard Lambernd $^{1} \cdot$ Aviral K. Tiwari $^{2}$
}

Accepted: 27 June 2021 / Published online: 4 October 2021

(c) The Author(s) 2021

\begin{abstract}
Focusing on air emissions in South Korean provinces, we investigate whether economic growth has become greener since the implementation of the national green growth strategy in 2009. Given the relevance of regional elements in the economic and environmental policies, the focus lies on spatial aspects. That is, spillovers from nearby provinces are controlled for in a SLX model by means of the Han-Phillips estimator for dynamic panel data. Our results suggest mainly the existence of inverted N-shaped Environmental Kuznets curves for sulfur oxides $\left(\mathrm{SO}_{\mathrm{X}}\right)$ and total suspended particles (TSP). As the curves initially decrease strongly with increasing income, the main cleanup is achieved with the mean income level. However, abatement of the remaining TSP emissions only takes place at higher income levels. While the fixed effects estimations indicate that per capita $\mathrm{SO}_{\mathrm{X}}$ and TSP emissions have been significantly lower since 2009, the effects vanish once spatial interactions are taken into account and no evidence is found that regional economic growth has become greener. Apart from economic growth, population density and energy consumption are the main drivers of emission changes, with the latter having robust spatial spillovers. The respective spatial interactions decrease with increasing distance and become insignificant after $150 \mathrm{~km}$.
\end{abstract}

Keywords Air emissions · Green growth $\cdot$ Spatial econometric model $\cdot$ Environmental Kuznets curve $\cdot$ Republic of Korea

Statement of exclusive submission This paper has not been submitted elsewhere in identical or similar form, nor will it be during the first three months after its submission to the Publisher.

Erik Hille

Erik.Hille@hhl.de

Bernhard Lambernd

Bernhard.Lambernd@hhl.de

Aviral K. Tiwari

Aviral.Eco@gmail.com

1 HHL Leipzig Graduate School of Management, Jahnallee 59, 04109 Leipzig, Germany

2 Rajagiri Business School, Rajagiri Valley Campus, Kochi, Kerala 682039, India 


\section{Introduction}

Korea's miraculous development into a high-income economy was driven by a rapid industrialization and strong export orientation. The country's leading industries, which include electronics, automobiles, chemicals, steel, and shipbuilding, are capital-intensive and mostly organized in so-called industrial complex clusters. In these clusters the majority of the country's manufacturing output and roughly $80 \%$ of its exports are produced (NGII 2017). However, the importance of capital-intensive industries, paired with the dependence on imported fossil fuels, have resulted in energy, emission, and some material intensities that are among the highest in the OECD (OECD 2020). Recent problems regard in particular air pollution, which is the focus of this paper, in the form of fine dust emissions as well as air quality issues in the capital region (Jones and Yoo 2012; OECD 2020).

In order to lessen the issues related to the historic brown growth paradigm, the far-reaching National Strategy for Green Growth has been implemented from 2009 onwards. ${ }^{1}$ This national strategy sets the long-term policy framework until 2050, focusing on three main objectives: (1) to mitigate climate change and increase energy self-sufficiency, (2) to create new green growth engines, and (3) to become a forerunner in improving the quality of life, e.g. by reducing air pollution with strong local effects, such as sulfur oxides $\left(\mathrm{SO}_{\mathrm{X}}\right)$, nitrogen oxides $\left(\mathrm{NO}_{\mathrm{X}}\right)$, and total suspended particles (TSP) (GGGI 2015; Jones and Yoo 2012). The long-term plan has been specified in several medium- and short-term plans, including the First and Second Five-Year Plans for Green Growth (2009-2013 and 2014-2018). Besides nationwide initiatives, the greening of industrial clusters and numerous regional initiatives are crucial to achieve the green growth objectives. Concerning the former, the national government provided a list of priority industries most suitable for each region and has fostered the establishment of green clusters, by e.g. granting matching funds to more than 1000 entities (GGGI 2015). For instance, a green car industrial cluster has been set up in the Ulsan-Gyeongsangnam region, where the leading Korean car manufacturers are based. Local governments have also been encouraged to define their own regional green cluster plans and construct testbed facilities. Concerning the latter, several initiatives, often in urban areas, have strived to improve the quality of life. These initiatives include public investments in infrastructure, such as the deployment of natural gas and electric buses in Seoul (GGGI 2015) or seed funding for a smart grid project in Jeju province (Mathews 2012), as well as regulation incentives, such as the implementation of a cap-and-trade program for sulfur dioxide $\left(\mathrm{SO}_{2}\right)$, nitrogen dioxide $\left(\mathrm{NO}_{2}\right)$, and TSP emissions in the capital region (Jones and Yoo 2012). Overall, first evaluations have regarded the Korean green growth strategy as highly ambitious, but it remains unclear if its implementation will be a success story, particularly in the light of the recent air pollution problems, the capitalintensive goods production, and high fossil fuel consumption intensities (Kim et al. 2014; Mathews 2012).

Given the comparatively high air pollution and the relevance of regional elements in the green growth strategy, this paper uses province-level data to analyze the effect of economic growth on regional air emissions in Korea. In this context, we contribute to research in two main ways. First, we test for changes since the launch of the National Strategy for Green Growth. Specifically, we specify general changes in air emissions with strong

\footnotetext{
${ }^{1}$ Given the historic growth paradigm, according to several policy stringency indicators, Korea was not necessarily known as a forerunner in environmental and climate protection among OECD countries before the launch of the green growth strategy (Althammer and Hille 2016; OECD 2020).
} 
local effects, focusing on per capita $\mathrm{SO}_{\mathrm{X}}$ and TSP emissions, and look for changed growth effects by adapting the classic Environmental Kuznets curve (EKC) framework. In other words, our analysis concentrates on the 3rd main objective of the green growth strategy, i.e. to improve the quality of life by reducing air pollution, and provides regional evidence. Already before the green growth strategy, both $\mathrm{SO}_{\mathrm{X}}$ and TSP have been subject to governmental regulation, because of their strong impacts on health and the environment paired with the availability of abatement technologies. ${ }^{2} \mathrm{SO}_{\mathrm{X}}$ is a main acid rain precursor and can cause illnesses, such as pneumonia, bronchitis, asthma, and emphysema. Similarly, besides adversely affecting plant growth, particle pollution can cause cancer, asthma, allergies, as well as cardiovascular and respiratory diseases (NIER 2020). As we consider data from 1999 to 2016, this is the first ex-post study of growth effects on emissions to analyze the First Five-Year Plan for Green Growth. Hence, we provide first evidence whether the postulated stronger commitment entailed an improvement in Korean air quality and a greening of economic growth. Moreover, the period allows considering the development of high fine dust emissions during recent years and detecting its main drivers. Our results suggest that, in order to become a forerunner in improving the quality of life, policy makers need to intensify the initiatives of the green growth strategy.

Second, we control for spatial interactions between provinces and contribute to spatial econometric research on the growth-environment nexus. On the one hand, given the importance of industrial clusters in Korea in general as well as of regional initiatives in the green growth strategy, this paper provides new spatial econometric evidence of the growth effects on air emissions for a country that has rarely been explored at the regional level. For this reason, we analyze data on 16 province-level divisions. ${ }^{3}$ While relatively few studies have applied spatial econometric approaches in general, focusing mostly on growth effects in China and few highly developed economies (Auffhammer and Steinhauser 2007; Cole et al. 2013; Zhao et al. 2014), a very limited number of studies on Korea has considered regional environmental data at all (Choi et al. 2015; Park and Lee 2011). Controlling for spatial interactions is important, because air emissions are inherently spatial. In other words, they are distributed by the wind, and therefore economic activity within regions that are close to each other, tends to affect one another's emissions (Burnett et al. 2013). Similarly, regions typically also interact through other channels, such capital and trade flows, technological spillover, and common environmental policies (Meng and Huang 2018). That is, these factors and air pollution across regions are in parts not independent, and thus neglecting spatial interactions may bias the estimated relationships or lower the efficiency

\footnotetext{
${ }^{2}$ In South Korea, ambient air emissions have been regulated nationally under the Clean Air Conservation Act as well as more recently starting from 2002 also regionally under standards and other policy instruments established in several metropolitan areas. As a main source of acid rain, $\mathrm{SO}_{2}$ has been regulated fairly early through a national emission standard, which dates back to 1978 and was gradually raised in 1993 and 2001 (ICCT 2020). Similarly, for TSP, a national emission standard was implemented in 1983. While a specific standard for sub-10 $\mu$ m particulate matter $\left(\mathrm{PM}_{10}\right)$ was added to the Clean Air Conservation Act in 1995, the general measure TSP was exempt in 2001 (ICCT 2020). Through its third objective, the national green growth strategy has again explicitly focused on the reduction of suspended particles pollution, and $\mathrm{SO}_{\mathrm{X}}$ is also among the main local air emissions to be reduced (Jones and Yoo 2012).

${ }^{3}$ Specifically, we consider data on 8 provinces, 6 metropolitan cities, the special city Seoul, and the special autonomous province Jeju. Figure 2 in Appendix A provides a map of the 16 divisions. For simplicity, we refer to the different divisions in a general context as provinces. As Sejong only became a special autonomous city in 2012, by merging mostly townships from Chungcheongnam province, the figures from Chungcheongnam and Sejong are considered jointly from 2012 onwards. In general, the figures for Sejong are relatively small, and the omission of the joint figures does not change our main findings.
} 
of the estimator (Cole et al. 2013). On the other hand, we contribute to spatial econometric analyses in general by estimating a spatial lag of $X$ (SLX) model using the Han-Phillips estimator for dynamic spatial panel data. This is an estimator developed more recently to control for potential endogeneity, while avoiding weak moment condition problems and biases in small samples. Prior spatial studies on the growth-environment nexus considered mostly three classic spatial models, i.e. spatial Durbin, spatial lag, and spatial error models, through maximum likelihood estimation (Burnett et al. 2013; Cole et al. 2013), and frequently do not control for simultaneity of explanatory variables other than for a spatially lagged dependent variable (Balado-Naves et al. 2018; Kang et al. 2016).

The paper continues as follows. While in Sect. 2 a theoretical background is given on models used to assess the growth-environment nexus, Sect. 3 summarizes the relevant empirical literature, focusing on spatial studies and research on Korea. Section 4 provides the descriptive statistics on the regional development of economic growth and the two air emissions with strong local effects. In Sect. 5, the fixed effects model, the spatial econometric model, and the data sources are introduced. Section 6 discusses the regression results. Last, Sect. 7 provides a summary of the findings as well as policy recommendations.

\section{Theoretical Background}

The growth-environment relationship has been analyzed comprehensively over the last decades. The traditional view on the relationship predicted a rising pollution level with increasing economic activity (Cleveland et al. 1984; Ehrlich and Holdren 1971; Meadows et al. 1972). However, this rested on the assumption that only the scale of economic activity changes, not the structure and technology. In particular, Grossman and Krueger (1991, 1995) shaped the scientific discussion by formulating the concept that has come to be known as the EKC hypothesis. ${ }^{4}$ The classic EKC hypothesis predicts an inverted U-shaped relationship between per capita income and environmental degradation.

The shape of the EKC is often interpreted as the result of scale, composition, and technique effects (Brock and Taylor 2005; Shahbaz and Sinha 2019). In the earlier stages of economic development, the scale effect, through increased economic activity, and the composition effect, through a structural change from primarily agricultural production to more resource-intensive industrial production, tend to dominate the effect on the environment. This drives up per capita environmental pollution until a certain level of income is reached. In the later development stages, the technique effect, through the implementation of cleaner technologies and stricter environmental policies, and the composition effect, through a structural change towards light industries and service sectors, tend to decrease pollution levels.

The theoretical foundation for the environmental impacts of economic growth has been discussed on the basis of static and dynamic models (Stern 2017). ${ }^{5}$ In the typical static version, a representative agent maximizes a utility function depending on consumption and pollution levels (Andreoni and Levinson 2001; Lieb 2002; Pasten and Figueroa 2012). The production function uses capital and pollution as inputs. Technological progress is assumed to be exogenous, and negative externalities are efficiently internalized by

\footnotetext{
${ }^{4}$ Other early contributions to the EKC are Selden and Song (1994) and Shafik (1994).

${ }^{5}$ Further overviews of theoretical models on the growth-environment nexus are provided in Brock and Taylor (2005), Carson (2010), Kijima et al. (2010), and Pasten and Figueroa (2012).
} 
policy. In the optimal solution, the marginal rate of substitution determines the supply of pollution, and the marginal product of pollution determines the demand for pollution. The relationship between economic growth and the environment is then described by the effect of a higher income on the willingness to pay for a marginal reduction of pollution and the opportunity costs of a marginal improvement of environmental quality. The curvature of the EKC depends on the elasticity of substitution in production between capital and pollution and the elasticity of the marginal utility of income. These kinds of models allow distinguishing between preferences or technologies as the driving forces behind the EKC, i.e. a higher willingness to pay for a cleaner environment or a cheaper replacement of pollution by capital.

Dynamic models are more diverse, ranging from neoclassical growth models, such as Green Solow models (Brock and Taylor 2010; Cherniwchan 2012), to endogenous growth models (Dinda 2005; Smulders et al. 2011). They allow a deeper analysis of the development process and its impact on the evolution of pollution, as well as of the role of technological progress and policy choices. For instance, technological progress in goods production creates a scale effect and increases emissions, whereas technological progress in abatement creates a pure technique effect that reduces emissions (Brock and Taylor 2005). As in the static models, in models with one consumption good, the driving forces for the EKC are substitution elasticities in the consumption and production function and the elasticity of the marginal utility of income. Multi-product endogenous growth models also allow the inclusion of a composition effect (e.g. Lopez and Yoon 2014). In theoretical models, precise conditions on the relevant elasticities that must be satisfied for a sustainable growth path can be derived, but these conditions are often restricted to specific functional forms.

\section{Related Empirical Literature}

The vast empirical literature on the growth-environment nexus is e.g. summarized in Carson (2010), Shahbaz and Sinha (2019), and Stern (2017). While using a variety of estimation techniques, studies have found different patterns of the relationship between income and environmental degradation that depend mainly on the type of environmental pollution and country-specific characteristics. For instance, studies on the EKC detected different shapes of the simple relationship, ranging from the classic inverted U-shape, to U-shapes, $\mathrm{N}$-shapes, inverted $\mathrm{N}$-shapes, as well as monotonic relationships.

Comparatively few articles have applied spatial econometric approaches to control for the influence of economic development in neighboring regions on environmental pollution. Most of the studies have focused on the spatial effects in China (Kang et al. 2016; Meng and Huang 2018; Zhao et al. 2014) and in few highly developed countries, especially the U.S. (Auffhammer and Steinhauser 2007; Cole et al. 2013; Rupasingha et al. 2004). ${ }^{6}$ The studies used predominantly one or several of three of the classic spatial models, i.e. a spatial Durbin, a spatial lag, and/or a spatial error model, and did not yet apply the spatial estimators introduced more recently. ${ }^{7}$ For instance, Burnett et al. (2013) estimated the

\footnotetext{
6 The studies on the closely related growth-energy consumption literature that used spatial econometric estimators have mainly focused on China (Hao et al. 2016; Jiang et al. 2014; Yu 2012).

7 Recent overviews of the different common spatial econometric models are e.g. provided in Elhorst (2017) and Halleck Vega and Elhorst (2015).
} 
effect of economic activity on U.S. state-level carbon dioxide $\left(\mathrm{CO}_{2}\right)$ emissions using the three mentioned classic models. They find that a spatial lag model with fixed effects is the most appropriate model for their data and that state-level increases in the GDP per capita imply increases in per capita emissions of neighboring states. Kang et al. (2016) used a spatial Durbin model with spatial and time fixed effects to examine the shape of the EKC for $\mathrm{CO}_{2}$ emissions in China. The authors confirm the existence of spatial spillover effects and find an inverted N-shaped curve. In Cole et al. (2013), the $\mathrm{CO}_{2}$ emissions of Japanese firms are analyzed by estimating a variety of spatial models. They detect that the pollution patterns of neighboring firms influence each other and recommend to accommodate these spatial spillover effects in future research. Besides single country studies, a small number of studies has analyzed the spatial interactions across countries (Balado-Naves et al. 2018; Maddison 2006; Rios and Gianmoena 2018). For example, Maddison (2006) investigated the spillover effects between 135 countries in an EKC framework and finds strong effects of $\mathrm{SO}_{2}$ and $\mathrm{NO}_{\mathrm{X}}$ emission intensities on the respective intensities of neighboring countries. Hence, most studies applying spatial econometrics to the growth-environment relationship conclude that spatial effects need to be accounted for. However, to the best of our knowledge, so far no study in the international literature on Korea has used a spatial estimator to control for regional spillovers on pollution.

Prior research on Korea has mainly employed three different methodologies. The first research stream has used decomposition analyses to determine the main drivers of emission changes, focusing predominantly on national greenhouse gas emissions (Lim et al. 2009; Oh et al. 2010; Sonnenschein and Mundaka 2016). While the analyses studied different factors, they generally conclude that economic growth is the strongest individual driver of increases in emissions in Korea. The second research stream has applied causality tests and correlation analyses to determine the relationships between economic growth and countrylevel emissions. For instance, Kim et al. (2010) find no evidence for a linear Granger causality between economic growth and $\mathrm{CO}_{2}$ emissions in Korea, but for a nonlinear two-way causality. Park and Hong (2013) used a Markov switching model to detail their correlation analysis and detect that economic growth and $\mathrm{CO}_{2}$ emissions are coincidental.

The third research stream has analyzed the shape of the EKC. For example, Choi et al. (2011) ran a simple OLS estimation to investigate the relationship between $\mathrm{CO}_{2}$ emissions, income, and trade openness. They find no evidence for the existence of an inverted U-shaped EKC in Korea. Baek and Kim (2013) used an autoregressive distributed lag (ARDL) model and controlled for energy consumption as well as electricity production from fossil fuels and nuclear energy. Their results support the existence of a conventional EKC for $\mathrm{CO}_{2}$ emissions, and highlight the polluting effect of energy consumption and fossil fuels electricity production. Two prominent studies that estimated EKCs for Korea focused on regional data. On the one hand, Choi et al. (2015) analyzed the impact of economic growth on the water quality in four major Korean rivers. Their fixed effects estimates provide partial evidence for an inverted U-shaped EKC for biochemical oxygen demand (BOD) and chemical oxygen demand (COD). On the other hand, Park and Lee (2011) used a dataset closest to ours. Specifically, they estimated the relationship between income and $\mathrm{SO}_{2}, \mathrm{NO}_{2}$, and carbon monoxide (CO) emissions in 16 Korean provinces, employing fixed and random effects models. Their results suggest a U-shaped relationship for $\mathrm{CO}$ emissions and region-specific curves for $\mathrm{SO}_{2}$ and $\mathrm{NO}_{2}$ emissions. Moreover, energy consumption is identified as the most important driver of air emissions. While Park and Lee (2011) controlled for population density, energy consumption, the number of registered vehicles, and the importance of the secondary sectors, they also point out that the omission of further region-specific factors could potentially bias the estimates. Overall, studies on Korea 
detect no single dominant relationship between economic growth and air emissions. Not surprisingly, energy consumption that has been sourced predominantly from fossil fuels, was often identified as a main driver of emission increases.

\section{Development of Air Emissions and Economic growth}

As introduced before, Korea is among the OECD countries with the highest energy and emission intensities. However, while on average the per capita gross regional product increased annually during the past years, air emissions with primarily strong local effects developed heterogeneously. Specifically, on the aggregate national level, per capita $\mathrm{SO}_{\mathrm{X}}$ emissions tended to decrease and per capita TSP emissions increased strongly. This holds true for both the overall analyzed period from 1999 to 2016 and the years since the launch of the National Strategy for Green Growth in 2009, when per capita $\mathrm{SO}_{\mathrm{X}}$ decreased by $33 \%$ and $11 \%$ and TSP grew by $556 \%$ and $278 \%$, respectively (NIER 2020).

The detailed province-level per capita gross regional product, $\mathrm{SO}_{\mathrm{X}}$ emissions, and TSP emissions are displayed in Fig. 1 for the years 1999 and $2016 .{ }^{8}$ Similar to the aggregate values, the per capita gross regional product increased in all provinces between the two years. While the metropolitan cities Ulsan and Daegu remained the two provinces with the highest and lowest figures, respectively, several other provinces experienced remarkable economic growth. In particular in Chungcheongnam province, the per capita gross regional product grew by $141 \%$ during the analyzed period, such that it became the province with the second highest figure in 2016. The strong growth may be explained by the structural change from an agricultural province to one focusing on industrial production, where several of Korea's major export goods are produced nowadays.

By contrast, apart from two provinces, i.e. Chungcheongnam (incl. Sejong) and Jeollanam, per capita $\mathrm{SO}_{\mathrm{X}}$ emissions decreased in all provinces between 1999 and 2016. In this context, provinces with relatively high and low emissions tend to remain as such, indicating a certain persistency of the industrial structure and type of machinery installed. That is, the three provinces with the lowest per capita $\mathrm{SO}_{\mathrm{X}}$ emissions and the two provinces with the highest were the same in 1999 and 2016. There also appears to be a linkage between provinces' emissions and the level of economic development. For instance, in 2016, the three provinces with the highest and lowest per capita $\mathrm{SO}_{\mathrm{X}}$ emissions and gross regional product were identical. The only exception to this pattern is Seoul, where the secondary sector is comparatively less important for value creation. Similarly, the two provinces where per capita $\mathrm{SO}_{\mathrm{X}}$ emissions increased and decreased strongest during the analyzed period are also among the three provinces with the highest and lowest per capita gross regional product in 2016, respectively.

Per capita TSP emissions developed rather dynamically. Except for the industrial center Ulsan, which had the highest suspended particles pollution in 1999, per capita TSP emissions strongly increased in every province between 1999 and 2016. While the three provinces with the lowest figures remained unchanged during the whole period, the three provinces with the highest pollution are different. As for $\mathrm{SO}_{\mathrm{X}}$, per capita TSP emissions tended to be relatively low in Seoul and most of the metropolitan cities. Nonetheless, compared to other capitals of OECD countries, the air emissions are relatively high (Jones and

\footnotetext{
8 A corresponding map with the names of the provinces is provided in Fig. 2 in Appendix A.
} 
Yoo 2012). Moreover, in line with prior research, TSP emissions appear to be related to $\mathrm{SO}_{\mathrm{X}}$ emissions, particularly in the autonomous cities (Sharma et al. 2014). For example, the three provinces with the lowest per capita TSP emissions, which are autonomous cities, were also persistently those with the lowest $\mathrm{SO}_{\mathrm{X}}$ values. Despite this, a clear pattern between province-level TSP emissions and the gross regional product cannot be deducted from the descriptive statistics.

\section{Methodology and Data}

\subsection{Fixed Effects Model}

As a benchmark for the spatial model, we first use the fixed effects estimator to analyze the relationship between emissions, economic growth, and the green growth policy by adapting the classic EKC framework ${ }^{9}$ :

$$
\ln E_{i t}=\alpha_{0}+\alpha_{1} I N C_{i t}+\alpha_{2} I N C_{i t}^{2}+\alpha_{3} I N C_{i t}^{3}+\alpha_{4} \text { GreenGrowth }+\left(\text { GreenGrowth } * I N C_{i t}^{l}\right) \beta_{l}+Z_{i t}^{\prime} \beta_{m}+\mu_{i}+\mu_{t}+\varepsilon_{i t}
$$

That is, per capita emissions $E$ in province $i$ and year $t$ are a function of the per capita gross regional product INC. Squared and cubic terms of $I N C$ are included to allow flexibility concerning the shape of the varied relationship. GreenGrowth denotes a binary variable that is 0 until the year 2008 and takes the value of 1 after the implementation of the green growth strategy from 2009 onwards. The coefficient of the binary variable will indicate if the emission level has, after controlling for changes in covariates, generally changed following the implementation of the national strategy. To test if specifically the growth effect has changed, the GreenGrowth variable is interacted with the three gross regional product terms. Moreover, $Z$ represents a vector of control variables, $\mu_{i}$ and $\mu_{t}$ are province and time fixed effects, and $\varepsilon$ denotes the error term.

Vector $Z$ comprises eight control variables. The first four covariates are included to replicate a parsimonious model similar to Park and Lee (2011), who also analyzed province-level air emissions in Korea. First, the paper controls for the population density of provinces. A rise in population density has been estimated to both increase (Auffhammer and Carson 2008; Park and Lee 2011) and decrease emissions (Selden and Song 1994; Zhao et al. 2014). While migration to urban areas may increase energy consumption due to a more consumption-oriented lifestyle, a larger population density can also optimize the spatial use of resources and increase the pressure on administrators to reduce pollution promptly, because more people are likely to be affected. Second, the combustion of fossil fuels, which accounts for the majority of Korea's energy consumption, results in emissions of a number of air pollutants, including $\mathrm{SO}_{\mathrm{X}}$ and TSP. Consequently, studies have found that a higher energy consumption in general and fossil fuel consumption in particular drive emission increases (Cole et al. 2005; Shahbaz and Sinha 2019), and we include provincespecific final energy consumption as a second control. Third, motor vehicles are considered a main source of air emissions, such as fine dust, and, therefore, studies have controlled for their registered number (Auffhammer and Carson 2008; Park and Lee 2011). Fourth, the capital-labor ratio is included, because secondary sectors (Jiang et al. 2014) and in

\footnotetext{
9 We performed a robust Hausman test, indicating that a fixed effects model is preferable to a random effects model. Examples of non-spatial results using alternative panel estimators are discussed in Sect. 6.3.
} 

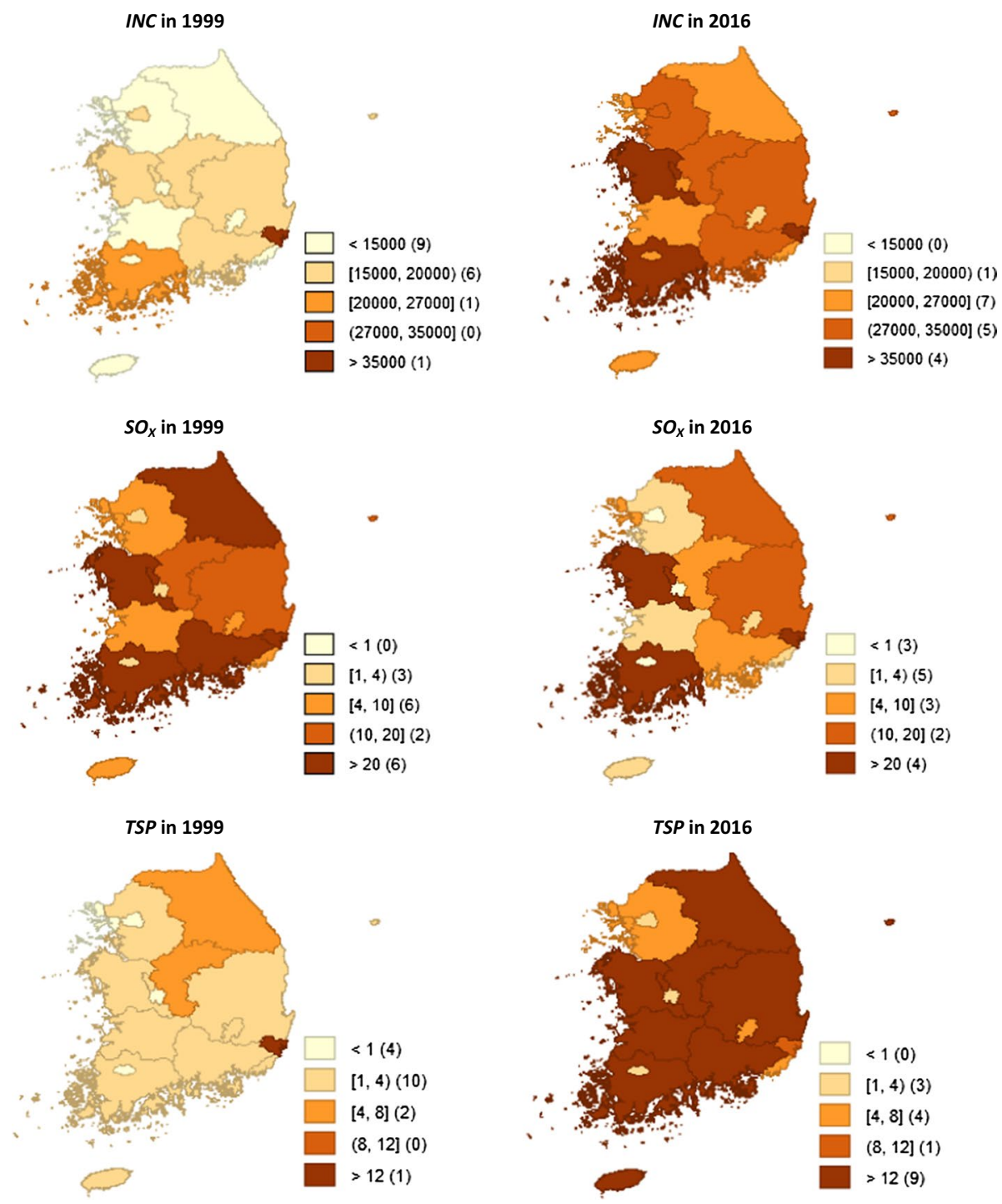

Fig. 1 Per capita gross regional product and emissions by provinces in 1999 and $2016^{\mathrm{a}}$, b ${ }^{\mathrm{a}} I N C$ denotes the per capita gross regional product in thousand Won 2010 prices, and the per capita emissions are in kilograms; bSelf-prepared using KOSIS (2020) and NIER (2020)

particular capital-intensive sectors tend to be relatively pollution-intensive (Cole et al. 2005). ${ }^{10}$ As province-specific capital stock data is not available, we estimate it following

\footnotetext{
${ }^{10}$ In addition to income terms, studies on the trade, growth and environment nexus often include the capital-labor ratio as a measure of economic composition and the pattern of production (Antweiler et al. 2001; Hille and Shahbaz 2019; Zugravu-Soilita 2017). As the capital-labor ratio of wealthier countries tends to be higher, we may expect to introduce collinearity issues. Yet, the variance inflation factor of both variables is well below ten, indicating that this is not a substantial concern for our sample. One explanation may be the partly heterogeneous economic structure on the provincial level. For instance, Ulsan's economy
} 
the methodology in Hille et al. (2019). ${ }^{11}$ The province-level total annual working hours of employed people proxy the labor stock.

The four remaining control variables mainly represent factors, which Park and Lee (2011) suggested being relevant to avoid omitted variable bias, but could not control for due to a lack of province-specific data. ${ }^{12}$ That is, fifth, we include R\&D expenditures, which are a frequently used measure of innovation activity (Balsalobre-Lorente et al. 2018; Cole et al. 2013; Hille and Lambernd 2020). The Korean green growth strategy focuses explicitly on a creative economy and, thus, technological change. Investments in R\&D are likely to induce innovations. In particular, process innovation may increase the resource efficiency, implying a lower use of resource inputs and reduced emissions, ceteris paribus. Sixth, environmental expenditures of the government signal its commitment to protect the environment and have sometimes been used to measure environmental policy stringency (Brunel and Levinson 2016). ${ }^{13}$ As public sector expenditures for environmental protection only are not publicly available on the provincial level and as we focus on air emissions with relatively strong local health effects, the government expenditures on the environment, health, and welfare are used as an approximation. Seventh, a related line of research has analyzed the environmental effects of FDI inflows. In general, there exist two conflicting hypotheses, namely the pollution haven and the pollution halo hypotheses, resulting in mixed expectations about the air emission effect (Zugravu-Soilita 2017). ${ }^{14}$ Last, a higher educational attainment may be associated with higher demands for environmental quality and, thus, lower air emissions (Hille et al. 2019). ${ }^{15}$ We estimate the average educational attainment of the economically active population based on their highest level of education.

\section{Footnote 10 (continued)}

strongly depends on heavy industries, whereas Seoul is characterized by a large service sector. Nonetheless, as some scholars used alternative proxies, such as the share of the industry sector in the GDP (Jiang et al. 2014; Meng and Huang 2018), we estimated alternative specifications and provide an example of results in Sect. 6.3.

11 Hille et al. (2019) determined base year capital stocks for the Korean provinces with the help of nationallevel sector-specific capital stocks for different asset classes and the province-specific share of value added for each sector. The province-specific capital stocks of the remaining years were estimated based on the perpetual inventory method using province-level information on fixed capital formation and depreciation.

12 Specifically, Park and Lee (2011) did not control for province-specific differences in labor characteristics, environmental regulations, energy prices, and technological development. Instead, they checked the robustness of their results using national-level Korean data for these factors.

13 Nonetheless, we do not intend to interpret this variable as a measure of regulatory stringency, because some public sector expenditures, such as subsidies to reduce pollution, reduce private sector abatement costs, and hence the effect on regulatory stringency is ambiguous (Brunel and Levinson 2016).

14 The pollution haven hypothesis argues that trade liberalization provides an incentive for foreign firms to relocate dirty goods productions to host countries with less stringent environmental policy, increasing pollution there. In contrast, under the pollution halo hypothesis, investments of foreign firms lead to a cleanup in the host country through knowledge and technology spillovers, as these firms may apply universal environmental standards and management practices (Zugravu-Soilita 2017). A differentiated picture on FDI inflows also seems to exist for Korea. While Aden et al. (1999) found that foreign firms in the textile and petrochemicals sector devoted fewer resources to pollution abatement than their Korean counterparts, Hille et al. (2019) showed that FDI inflows reduced air emission intensities in Korea, when indirect effects are accounted for.

15 Educational attainment has also been used as a measure of human capital (Barro and Lee 2013). In this context, studies found that human capital intensity both increased and decreased pollution intensity (Cole et al. 2005, 2013; Lan et al. 2012; Sapkota and Bastola 2017). A possible explanation for the harmful effect is that pollution-intensive industries tend to rely on complex processes that require skilled labor (Cole et al. 2005). Similarly, human capital is related to technological skills, which enable the adoption of more advanced, cleaner technologies, and thus can lead to a cleanup effect (Lan et al. 2012). 
Specifically, we set the average number of education years of elementary school to six years and of middle school, high school, college, and university to nine, twelve, 16, and 19 years, respectively. An overview of all variables and the corresponding regular descriptive statistics are provided in Table 4 in Appendix A.

\subsection{Spatial Econometric Model}

While Eq. (1) considers the effect of changes in activities within a province on its air emissions, it does not control for potential spatial spillovers outlined in the introduction. To avoid biases in the estimated parameters, we control for these spillovers on air emissions from nearby provinces by including so-called exogenous spatial interaction effects $W X$. Specifically, we analyze the following dynamic spatial econometric model using the Han-Phillips estimator:

$$
\begin{aligned}
\ln E_{i t}= & \delta_{1} \ln E_{i t-1}+\alpha_{0}+\alpha_{1} I N C_{i t}+\alpha_{2} I N C_{i t}^{2}+\alpha_{3} I N C_{i t}^{3}+\alpha_{4} \text { GreenGrowth }+\left(\text { GreenGrowth } * I N C_{i t}^{l}\right) \beta_{l} \\
& +Z_{i t}^{\prime} \beta_{m}+\sum_{j=1}^{n} W_{i j} X_{j}^{\prime} \theta+\mu_{i}+\mu_{t}+\varepsilon_{i t}
\end{aligned}
$$

where $E_{t-1}$ are one-year lagged per capita emissions capturing dynamic effects in the estimator. $W X$ is the interaction term of the spatial weight matrix $W$, which summarizes the dependence structure between jurisdictions, with a vector of explanatory variables $X$. In detail, $X$ includes observations for nearby provinces $j$ of all prior explanatory variable terms in Eq. (1), i.e. of terms including $I N C$, the green growth binary, as well as the vector of control variables $Z$. The remaining terms are analogous to the fixed effects model.

In spatial econometrics, the selection of the spatial model, the spatial weight matrix, and the estimator are central elements. Regarding the first element, Halleck Vega and Elhorst (2015) provide a recent overview of spatial econometric models that have been applied in the literature. The models vary in the extent that they control for spatial effects among the dependent variable, the independent variables, and/or the error term by including interaction effects of the weight matrix $W$ and the respective term. To test for possible spatial correlations, we perform Moran's I tests on the dependent and independent variables. The results that are reported in Table 5 in Appendix A for different weight matrices, indicate the general existence of spatial correlation and thus the importance to control for spatial interactions. In order to select the most appropriate spatial econometric model, recent model selection strategies focus on specifications, that include exogenous spatial interaction effects $W X$, as point of departure, because they impose no restrictions on the magnitude of spatial spillovers in advance (Halleck Vega and Elhorst 2015; LeSage 2014). Specifically, we follow the approach of LeSage (2014), who suggests that, depending on the nature of spillover effects, either the spatial Durbin model or the spatial Durbin error model should be taken as a point of departure. The former model implies rather global spatial spillovers through the included additional spatially lagged dependent variable, whereas the latter model leads to local spatial spillovers. As we consider air emissions with strong local effects, the spatial Durbin error model appears to be more appropriate. This reasoning is supported by the log marginal likelihood statistics, obtained using Bayesian postestimation, which overall favor the use of a SLX model. Similarly, likelihood ratio (LR) and Wald tests confirm that the SLX model is preferred for our analysis, when the spatial Durbin error model serves as a starting point. The SLX model is the simplest of the more 
flexible models, controlling for spatial interactions solely through exogenous interaction effects $W X .^{16}$

The selection of the spatial econometric model is conditional on the second important element, i.e. the design of the weight matrix. Studies of growth effects on the environment and energy use have most commonly utilized spatial contiguity weights, i.e. neighborhood matrices (Burnett et al. 2013; Kang et al. 2016; Jiang et al. 2014), and radial distance weights, i.e. distance matrices (Cole et al. 2013; Hao et al. 2016; Yu 2012). A weakness of using weights on the basis of a shared border, is the assumption that all neighbors have an equal influence and spatial interactions beyond neighbors are omitted (Yu 2012). However, spatial dependencies for air emissions with strong local effects are expected to exist within a certain distance rather than for neighboring provinces only. That is, when provinces are in parts of very different size, then the economic activities of nearby provinces can affect emissions, even if the provinces are not geographically contiguous. Given the large number of autonomous cities among the province-level Korean divisions, this argument seems particularly relevant to our analysis. For instance, the first and third largest autonomous city Seoul and Incheon do not share a common border, but are close to each other and located in one agglomeration. Therefore, we utilize a spatial weight matrix based on the distances between provincial capitals. ${ }^{17}$ As the provincial capitals tend to be the province's economic center and transportation hub, the distance can reflect not only pure geographic distance but also the economic distance (Yu 2012). Specifically, when the distance between the capitals of province $i$ and province $j$ is smaller than the threshold distance, then the corresponding element of the spatial weight matrix is 1 and 0 otherwise. As we focus on emissions with rather local effects, the threshold distance is set equal to $50 \mathrm{~km}$ in the main estimations. It is expected that wind distributes the various air emissions differently, and therefore the spatial spillovers will also vary depending on the air emission type. To show how the spatial spillovers change with increasing distance, we analyze different threshold distances, and report examples of results for $100 \mathrm{~km}$ and $150 \mathrm{~km}$ in the robustness checks Sect. 6.3.

As the main spatial econometric estimator, we use the Han-Phillips estimator for dynamic panel data. Models with spatial interaction effects can be estimated using various

\footnotetext{
16 Besides the more recent model selection approach, we also conducted the popular past model selection strategies (Elhorst 2010; Florax et al. 2003; LeSage and Pace 2009). Robust Lagrange Multiplier (LM) and Moran's $I$ (Error) tests, reported in Table 5 in Appendix A, indicate that spatial interaction effects among the dependent variables are not relevant for our analysis, whereas interactions among the error terms partly are. Yet, the significant spatial autocorrelation in the error terms may as well be the result of the omitted $W X$ term, which is generally not considered in past tests (Elhorst 2017). When the spatial Durbin model is used as point of departure, LR and Wald tests also tend to support the selection of the SLX model. Nonetheless, for few analyzed specifications, the tests partly suggest that a spatial Durbin model should be adopted. In this context, it needs to be noted that, given the design of the LR-test, we compared the competing spatial econometric models for these tests based on the maximum likelihood estimates. Moreover, unlike the Bayesian approach, inferences of LR tests are conditional on the parameter estimates (LeSage 2014). We report examples of estimates for the spatial Durbin model and discuss the robustness of results in Sect. 5.3. Given the large number of performed tests, further detailed test results are not reported here, but are available upon request.

17 When a binary contiguity matrix is used, our main findings mostly remain unchanged. That is, for $\mathrm{SO}_{\mathrm{X}}$, we generally find robust estimates for the direct effects and, apart from additional significant spatial effects of population density, the same variables have significant spatial effects. For TSP, more estimates change. In particular the partly significant direct effects of several control variables, i.e. the capital-labor ratio, R\&D expenditures, and educational attainment, become insignificant. For reasons of space, these results are available upon request.
} 
methods, such as maximum likelihood, instrumental variable (IV) or generalized methods of moments (GMM), and Bayesian Markov Chain Monte Carlo approaches. The main advantage of IV and GMM estimators is that they can be applied straightforwardly in cases where the model includes one or several endogenous explanatory variables, other than a spatially lagged dependent variable. For other estimators, this is difficult or impossible (Elhorst 2010). Models on the environmental effects of trade liberalization and economic growth may contain a number of potentially endogenous explanatory variables, including most often income and the trade measure (Hille et al. 2019; Managi et al. 2009; McAusland and Millimet 2013). Nonetheless, the large majority of spatial econometric analyses on the growth-environment relationship has neither controlled for these potentially endogenous variables nor employed IV and GMM estimators (Burnett et al. 2013; Kang et al. 2016; Zhao et al. 2014). Therefore, sufficiently accounting for endogeneity is still regarded as an important task for future spatial research in the field (Cole et al. 2013). Following prior non-spatial models, we consider income $I N C$ and our trade measure, i.e. FDI inflows, as potentially endogenous. To control for endogeneity concerns, this is the first spatial analysis on environmental effects that relies on the GMM estimation technique developed by Han and Phillips (2010). By applying the ideas of Phillips and Han (2008) to dynamic panel data models, the Han-Phillips estimator solves weak instrument problems and avoids biases in small samples as ours. These issues are often present in conventional IV/GMM approaches, such as of Anderson and Hsiao (1981) and Arellano and Bond (1991), when the autoregressive coefficient is close to unity (Han and Phillips 2010), or when neither a large number of observations nor many periods are analyzed (Hayakawa 2007), respectively.

\subsection{Data Sources}

We analyze emissions data on 16 Korean provinces for the period 1999 to $2016 .{ }^{18}$ The data was collected from a variety of sources. First, air emission levels were obtained from the National Institute of Environmental Research (NIER 2020). Second, the Korean Energy Economics Institute (KEEI 2018) provided the information on final energy consumption and the number of registered motor vehicles. Third, data on province-specific FDI inflows is not publicly available, but was supplied by the Korean Trade-Investment Promotion Agency (KOTRA 2017). Fourth, for the construction of the distance weight matrix, we calculated distances using geographic coordinates of the provincial capitals from Google Maps (2020). Last, the remaining information that is necessary to construct the variables was obtained from the Korean Statistical Information Service (KOSIS 2020). This includes data on the gross regional product, sectoral value added, capital stocks, capital formation and depreciation, government and R\&D expenditures, population size, employment, working hours, highest level of education, province areas, and deflators.

\footnotetext{
18 Throughout the paper, we analyze models with different lag structures. In order to ensure that our different estimations are comparable, data for the explanatory variables is used consistently from the period 2000 to 2015. The only exceptions are columns (35), (36), and (39), where we consider the lagged effect of R\&D expenditures and test the robustness to a change in statistics in 2015. As our SLX model includes a lagged dependent variable and we also analyze moving average emissions in the robustness tests, this implies that the data for the explained variables, i.e. the per capita emissions, can extend from 1999 to 2016. Our findings are robust when data for the whole period is considered in all estimations.
} 


\section{Results and Discussion}

\subsection{Fixed Effects Results}

Table 1 shows the fixed effects results of three different specifications for both $\mathrm{SO}_{\mathrm{X}}$ and TSP. Firstly, we estimate a parsimonious model in columns (1) and (4), i.e. besides the income terms and fixed effects, we control for population density, energy consumption, the number of motor vehicles, and the capital-labor ratio. The coefficients of per capita income INC indicate that, for our sample, the relationships with per capita $\mathrm{SO}_{\mathrm{X}}$ and TSP emissions should be best described as inverted N-shaped curves, which have been found in a number of prior studies (Dijkgraaf and Vollebergh 2005; Kang et al. 2016; Nasr et al. 2015). Figure 3 in Appendix B graphs the estimated curves for the sample's income range. As can be seen, for the fixed effects results, we do not consistently find fully developed inverted $\mathrm{N}$-curves. That is, although both per capita $\mathrm{SO}_{\mathrm{X}}$ and TSP emissions initially decrease strongly with increasing income, the curves then develop differently. The curve for $\mathrm{SO}_{\mathrm{X}}$ is strictly decreasing and does not have two turning points, but instead only an inflection point at 46.4 million Won. In other words, the middle stroke of the inverted $\mathrm{N}$ is missing, as the magnitude of the positive $I N C^{2}$ coefficient is comparatively small in the fixed effects estimations. ${ }^{19}$ The curve for TSP has two turning points at 28.4 and 40.6 million Won. As the curve is rather flat between the turning points, per capita TSP emissions increase only slightly after the first turning point and decrease again after the second turning point.

While the main cleanup has already been achieved for both $\mathrm{SO}_{\mathrm{X}}$ and TSP with the mean income level of 24.1 million Won, the importance of the additional reduction in per capita emissions at higher income levels varies. Specifically, the additional reduction is relatively small for $\mathrm{SO}_{\mathrm{X}}$ but large for TSP, amounting to more than $4 \mathrm{~kg}$ TSP per capita potential reductions until the maximum sample income level. The difference indicates that, on the one hand, the most important technologies to reduce $\mathrm{SO}_{\mathrm{X}}$ have been implemented relatively early. This is in line with the historical development and urgency to fight acid rain, which increased because of heavy industrialization from the late 1970s onwards. On the other hand, the curve for TSP suggests that discrete technologies have been deployed to reduce parts of the suspended particles pollution at relatively low income levels. However, more advanced technologies seem to require rather costly abatement expenditures that have only been spent once a certain income threshold is passed. In that regard, at higher income levels, the increased demand for environmental quality, reflected in the technique effect, seems to drive the growth effect on TSP.

Similar to our study, Park and Lee (2011) considered gross $\mathrm{SO}_{2}$ emissions in Korea, yet they do not provide reference points for TSP. Although Park and Lee (2011) find that the growth-environment nexus tends to be province-specific for $\mathrm{SO}_{2}$, they also detect monotonically decreasing relationships and potentially $\mathrm{N}$-shaped relationships with turning points at 8.2 and 40.0 million Won, which are close to their sample's boundary values. ${ }^{20}$ In

\footnotetext{
${ }^{19}$ By contrast, based on the spatial estimators, the EKC curves for $\mathrm{SO}_{\mathrm{X}}$ have a fully developed inverted $\mathrm{N}$-shape with two turning points. While the curves are almost flat between the turning points, most of the per capita $\mathrm{SO}_{\mathrm{X}}$ emission reduction is, analogous to the fixed effects estimates, still achieved at comparatively low income levels.

20 As our monetary values are in constant 2010 prices, Park and Lee's (2011) USD values in constant 2000 prices are converted using the exchange rate and price information from OECD (2020) and KOSIS (2020), respectively. Specifically, they find turning points at $\$ 5,700$ and $\$ 28,000$.
} 
other words, an increase in income is mostly associated with lower $\mathrm{SO}_{2}$ emissions. Interestingly, we find an analogous pattern for per capita $\mathrm{SO}_{\mathrm{X}}$ emissions. Nonetheless, our results are not fully comparable, because we analyze per capita emissions and a later time period with higher average income levels, and we interpret the fixed effects instead of the random effects estimates.

Apart from economic growth, the four control variables are, in parts, estimated to be strong drivers of per capita emissions. Specifically, increases in the population density POP/AREA are associated with the largest emission reductions for both $\mathrm{SO}_{\mathrm{X}}$ and TSP. This indicates that, for our sample, a higher resource efficiency and increased pressures to react to environmental problems outweigh other factors related to a rising population density. In line with Park and Lee's (2011) estimates for $\mathrm{SO}_{2}$, we find that energy consumption ENUSE is the control variable, which is related with the largest per capita $\mathrm{SO}_{\mathrm{X}}$ emission increases. ${ }^{21}$ Similarly, energy consumption is an important determinant for per capita TSP emissions. The relatively large and positive coefficients may be explained by the high share of fossil fuels in the Korean energy mix. While we find no significant relation between the number of registered motor vehicles $C A R S$ and $\mathrm{SO}_{\mathrm{X}}$ emissions, an increase in CARS is, as expected, associated with higher per capita TSP emissions. More precisely, the estimates suggest that registered motor vehicles, which rely predominantly on conventional powertrains emitting fine dust, are the main driver of per capita TSP emission increases. Marginally significant coefficients are detected for the capital-labor ratio $K / L$. As expected, an increase in $K / L$ is associated with higher per capita $\mathrm{SO}_{\mathrm{X}}$ emissions. The negative association of $K / L$ for TSP appears to be counterintuitive. However, as related important drivers of suspended particles, such as ENUSE and CARS, are also controlled for, the emission reduction through a higher capital-intensity may as well stem from more modern machinery.

Secondly, in order to avoid the omission of important emission determinants, we expand the first specification by including all control variables in columns (2) and (5). That is, we add $R \& D$ expenditures $R \& D$, government expenditures related to the environment $G O V$, FDI inflows $F D I$, and educational attainment $E D U$, and will use this specification as the base model in later estimations. While the coefficients of the variables from the previous specification largely remain unchanged compared to the respective estimates in columns (1) and (4), we only detect a significant association between FDI inflows and $\mathrm{SO}_{\mathrm{X}}$ emissions. Specifically, an increase in FDI inflows is associated with higher per capita $\mathrm{SO}_{\mathrm{X}}$ emissions in the fixed effects estimations, corresponding with the pollution haven argument. The insignificant associations may be attributed in part to our limited sample size as well as unconsidered simultaneity and spatial interactions in the fixed effects estimations. ${ }^{22}$

Thirdly, the green growth binary GreenGrowth is added to test whether there has been a general environmental cleanup in the form of lower per capita emissions after the launch of the National Strategy for Green Growth. The significantly negative coefficients for both $\mathrm{SO}_{\mathrm{X}}$ and TSP in columns (3) and (6) suggest that, ceteris paribus, per capita emissions have been lower since 2009 compared to the prior years. Technically, the negative coefficients

\footnotetext{
${ }^{21}$ For the other covariates, our estimates are different to those of Park and Lee's (2011) preferred specifications. That is, while population density is insignificant, they found that an increase in the number of registered motor vehicles and the capital-intensive industry sector are associated with significantly lower $\mathrm{SO}_{2}$ emissions, which is unexpected.

22 Besides partly different direct effect estimates in the spatial econometric analysis, we prefer to keep the covariates, because their inclusion does mostly not change the coefficients of the previously included variables, and they have been considered as important determinants by theory and in earlier analyses.
} 
Table 1 Fixed effects estimations

\begin{tabular}{|c|c|c|c|c|c|c|}
\hline $\ln (E)$ & $\begin{array}{l}(1) \\
S O_{X} \\
\text { Parsimonious }\end{array}$ & $\begin{array}{l}(2) \\
S O_{X} \\
\text { Base }\end{array}$ & $\begin{array}{l}(3) \\
S O_{X} \\
\text { GG intercept }\end{array}$ & $\begin{array}{l}(4) \\
\text { TSP } \\
\text { Parsimonious }\end{array}$ & $\begin{array}{l}(5) \\
T S P \\
\text { Base }\end{array}$ & $\begin{array}{l}(6) \\
\text { TSP } \\
\text { GG intercept }\end{array}$ \\
\hline$I N C$ & $\begin{array}{l}-0.304 * * \\
(0.105)\end{array}$ & $\begin{array}{l}-0.361^{* *} \\
(0.126)\end{array}$ & $\begin{array}{l}-0.409 * * * \\
(0.120)\end{array}$ & $\begin{array}{l}-0.428 * * \\
(0.173)\end{array}$ & $\begin{array}{l}-0.399 * \\
(0.200)\end{array}$ & $\begin{array}{l}-0.436^{*} \\
(0.210)\end{array}$ \\
\hline$I N C^{2}$ & $\begin{array}{l}0.006^{* *} \\
-(0.003)\end{array}$ & $\begin{array}{l}0.008^{* *} \\
-(0.003)\end{array}$ & $\begin{array}{l}0.009 * * * \\
(0.003)\end{array}$ & $\begin{array}{l}0.013 * * \\
(0.005)\end{array}$ & $\begin{array}{l}0.012 * * \\
(0.005)\end{array}$ & $\begin{array}{l}0.013 * * \\
(0.005)\end{array}$ \\
\hline$I N C^{3}$ & $\begin{array}{l}-0.00004 * \\
(0.00002)\end{array}$ & $\begin{array}{l}-0.00006^{* * *} \\
(0.00002)\end{array}$ & $\begin{array}{l}-0.00006^{* *} \\
(0.00002)\end{array}$ & $\begin{array}{l}-0.00012^{* * *} \\
(0.00004)\end{array}$ & $\begin{array}{l}-0.00012 * * \\
(0.00004)\end{array}$ & $\begin{array}{l}-0.00013^{* *} \\
(0.00004)\end{array}$ \\
\hline GreenGrowth & & & $\begin{array}{l}-0.207 * * * \\
(0.044)\end{array}$ & & & $\begin{array}{l}-0.157^{*} \\
(0.079)\end{array}$ \\
\hline $\ln (P O P / A R E A)$ & $\begin{array}{l}-2.886^{* * *} \\
(0.668)\end{array}$ & $\begin{array}{l}-3.273 \text { *** } \\
(0.789)\end{array}$ & $\begin{array}{l}-3.311 * * * \\
(0.793)\end{array}$ & $\begin{array}{l}-7.657 * * * \\
(1.366)\end{array}$ & $\begin{array}{l}-7.427 * * * \\
(1.669)\end{array}$ & $\begin{array}{l}-7.455^{* * *} \\
(1.707)\end{array}$ \\
\hline $\ln (E N U S E)$ & $\begin{array}{l}1.104 * \\
(0.524)\end{array}$ & $\begin{array}{l}1.099 * * \\
(0.500)\end{array}$ & $\begin{array}{l}1.098 * * \\
(0.482)\end{array}$ & $\begin{array}{l}2.477 * * \\
(1.071)\end{array}$ & $\begin{array}{l}2.523 * * \\
(1.104)\end{array}$ & $\begin{array}{l}2.523 * * \\
(1.121)\end{array}$ \\
\hline $\ln (C A R S)$ & $\begin{array}{l}-0.599 \\
(0.621)\end{array}$ & $\begin{array}{l}-0.639 \\
(0.620)\end{array}$ & $\begin{array}{l}-0.750 \\
(0.578)\end{array}$ & $\begin{array}{l}3.120 * * * \\
(0.835)\end{array}$ & $\begin{array}{l}2.945 * * * \\
(0.940)\end{array}$ & $\begin{array}{l}2.860 * * * \\
(0.933)\end{array}$ \\
\hline $\ln (K / L)$ & $\begin{array}{l}0.962 * \\
(0.494)\end{array}$ & $\begin{array}{l}0.767 \\
(0.451)\end{array}$ & $\begin{array}{l}0.894 * \\
(0.425)\end{array}$ & $\begin{array}{l}-1.458^{*} \\
(0.795)\end{array}$ & $\begin{array}{l}-1.210 \\
(0.922)\end{array}$ & $\begin{array}{l}-1.113 \\
(0.927)\end{array}$ \\
\hline $\ln (R \& D)$ & & $\begin{array}{l}0.223 \\
(0.164)\end{array}$ & $\begin{array}{l}0.268 \\
(0.154)\end{array}$ & & $\begin{array}{l}-0.193 \\
(0.217)\end{array}$ & $\begin{array}{l}-0.158 \\
(0.220)\end{array}$ \\
\hline $\ln (G O V)$ & & $\begin{array}{l}0.172 \\
(0.261)\end{array}$ & $\begin{array}{l}0.504 * * \\
(0.232)\end{array}$ & & $\begin{array}{l}0.0482 \\
(0.534)\end{array}$ & $\begin{array}{l}0.301 \\
(0.574)\end{array}$ \\
\hline $\ln (F D I)$ & & $\begin{array}{l}0.012 * * \\
(0.005)\end{array}$ & $\begin{array}{l}0.016^{* * *} \\
(0.005)\end{array}$ & & $\begin{array}{l}0.017 \\
(0.0253)\end{array}$ & $\begin{array}{l}0.020 \\
(0.026)\end{array}$ \\
\hline $\ln (E D U)$ & & $\begin{array}{l}-2.145 \\
(2.180)\end{array}$ & $\begin{array}{l}-2.314 \\
(2.093)\end{array}$ & & $\begin{array}{l}0.635 \\
(3.752)\end{array}$ & $\begin{array}{l}0.507 \\
(3.711)\end{array}$ \\
\hline Constant & $\begin{array}{l}15.17 * * * \\
(2.859)\end{array}$ & $\begin{array}{l}19.37 * * * \\
(2.987)\end{array}$ & $\begin{array}{l}15.54 * * * \\
(3.159)\end{array}$ & $\begin{array}{l}18.85^{* *} \\
(8.676)\end{array}$ & $\begin{array}{l}16.91 * \\
(8.373)\end{array}$ & $\begin{array}{l}14.00 \\
(8.556)\end{array}$ \\
\hline Observations & 256 & 256 & 256 & 256 & 256 & 256 \\
\hline$R^{2}$ within & 0.515 & 0.540 & 0.568 & 0.359 & 0.362 & 0.356 \\
\hline$R^{2}$ between & 0.568 & 0.550 & 0.533 & 0.642 & 0.654 & 0.646 \\
\hline$R^{2}$ overall & 0.550 & 0.532 & 0.516 & 0.491 & 0.500 & 0.494 \\
\hline$F$-statistic & $17.04 * * *$ & $27.11 * * *$ & $36.13^{* * *}$ & $50.13^{* * *}$ & $60.29 * * *$ & $60.30^{* * *} *$ \\
\hline
\end{tabular}

$* * * p<0.01 ; * * p<0.05 ; * p<0.10$; robust standard errors are in parentheses

imply a downward shift of the inverted $\mathrm{N}$-shaped curves for a given income. However, as can be seen in Fig. 3 in Appendix B, the difference between the median per capita emissions before and after the launch of the green growth strategy decreases with increasing income, because per capita emissions are in logarithmic terms. ${ }^{23}$

\footnotetext{
${ }^{23}$ We also estimated our models for other important air emissions, such as $\mathrm{CO}, \mathrm{NO}_{\mathrm{X}}$, and $\mathrm{PM}_{10}$. The fixed effects results suggest the existence of inverted $\mathrm{N}$-shaped EKCs for per capita $\mathrm{CO}$ and $\mathrm{PM}_{10}$ emissions. In this context, the findings for $\mathrm{PM}_{10}$ are, as expected, congruent with those for TSP. By contrast, no dominant relationship is found between income and per capita $\mathrm{CO}$ emissions, which is not an unusual finding for EKC studies (Shahbaz and Sinha 2019). Interestingly, both per capita $\mathrm{NO}_{\mathrm{X}}$ and $\mathrm{PM}_{10}$ emissions are esti-
} 


\subsection{Spatial Econometric Results}

Tables 2 and 3 report the spatial econometric results of the Han-Phillips estimator for $\mathrm{SO}_{\mathrm{X}}$ and TSP, respectively, controlling for spatial interactions between nearby provinces. The estimates of three specifications are shown. That is, firstly, in columns (7) and (10), we estimate a dynamic model that corresponds to the base specification in Table 1, by adding the respective spatially weighted explanatory variables as well as a lagged dependent variable. ${ }^{24}$ For each column, we display both direct effects on province's per capita emissions $E$ associated with changes in the explanatory variables $X$ and in the lagged dependent variable $E_{t-1}$ in the province itself (Sub-columns $X$ ) and cumulative indirect spatial effects through changes in $X$ in nearby provinces (Sub-columns $W X$ ).

With regard to the direct effects, we detect analogous signs of the per capita income term coefficients, validating the inverted-N shaped growth-emissions relationship for our sample. Similarly, the role of population density and energy consumption as main drivers of emission changes is confirmed for both $\mathrm{SO}_{\mathrm{X}}$ and TSP emissions. The importance of the other control variables partly changed. For $\mathrm{SO}_{\mathrm{X}}$, changes in FDI inflows are not significant anymore. This may be explained by the comparatively low levels of FDI inflows into Korean provinces, ranging on average between 0.5 and $1.3 \%$ of the gross regional product between 1999 and 2016 (KOSIS 2020; KOTRA 2017). For TSP, increases in the capital-labor ratio are estimated to increase per capita emissions, whereas increases in R\&D expenditures and in particular in educational attainment decrease per capita emissions. The prior strong association of the number of registered motor vehicles is not confirmed by the Han-Phillips estimates. Instead, parts of the variation seem to be captured by the larger energy consumption coefficient.

The direct effects are partly enhanced by indirect spatial effects. In particular, rising energy consumption in nearby provinces, which is sourced largely from fossil fuels, significantly increases both per capita $\mathrm{SO}_{\mathrm{X}}$ and TSP emissions. This is in line with the relevance of energy consumption- and structure-related spatial spillovers found in prior analyses on the growth-environment nexus (Kang et al. 2016; Meng and Huang 2018; Zhao et al. 2014). While per capita $\mathrm{SO}_{\mathrm{x}}$ emissions are also significantly affected by economic activity in nearby provinces through the income terms, no corresponding spatial spillovers are estimated for TSP. Hence, apart from the indirect energy consumption effect, the determinants of TSP emissions appear to be rather local. This implies that, for our sample, suspended particles pollution is mainly concentrated in the area where it is emitted.

In columns (8) and (11), the green growth binary is included in the form of the GreenGrowth and WGreenGrowth terms. Compared to columns (7) and (10), only the prior marginally significant indirect spatial effect of the linear per capita income term $I N C$ on $\mathrm{SO}_{\mathrm{X}}$ emissions is not significant anymore, whereas those for $I N C^{2}$ and $I N C^{3}$ remain unchanged. Thus, the spatial spillovers of nearby provinces' economic activity are similar, yet less

\footnotetext{
Footnote 23 (continued)

mated to be significantly lower since the implementation of the green growth strategy. Further details are available upon request.

${ }^{24}$ For space reasons, the estimations analogous to the first specification of the fixed effects results are only reported in Appendix B and shortly discussed in the robustness checks Sect. 6.3. Moreover, analyses on the determinants of environmental pollution have also considered specifications with linear and squared income terms only (Auffhammer and Carson 2008; Maddison 2006; Yu 2012). Examples of the corresponding estimates, which are reported in Table 6 in Appendix B, result in analogous effects for the control variables and support the picture that per capita $\mathrm{SO}_{\mathrm{X}}$ and TSP emissions tend to decrease with increasing income levels.
} 
pronounced for relatively low incomes. More importantly, we only find insignificant direct and indirect coefficients of the green growth binary. That is, while the fixed effects results in Table 3 suggest that per capita $\mathrm{SO}_{\mathrm{X}}$ and TSP emissions have been significantly lower since the launch of the green growth strategy, the effects vanish once emission spillover from nearby provinces are taken into account. In other words, we do not find clear evidence that the measures taken in the course of the green growth strategy have so far led to a general improvement in air quality at the regional level. Our estimates also show the importance to control for spatial interactions, as some of the omitted spatial spillovers appear to be wrongly associated with the green growth binary in the fixed effects estimations.

Even though no general change in per capita $\mathrm{SO}_{\mathrm{X}}$ and TSP emissions are detected, the regional growth effects may have been influenced by the green growth initiatives. Therefore, interaction effects of the green growth binary with the income terms are added to the model. As can be deducted from the insignificant corresponding coefficients in columns (9) and (12), it is also unlikely that regional economic growth has become greener. In other words, while per capita emissions also tended to decrease or at least remained fairly constant with growing income, because of the shape of the EKCs and economic growth in every province, a shift in and thus greening of the growth paths cannot be observed for the period since the implementation of the green growth strategy in 2009. Moreover, in this specification, in particular for TSP, a number of coefficients become insignificant, i.e. the income terms, the capital-labor ratio, and R\&D expenditures. This is not entirely surprising, because the effect of income is further split up in the direct and interaction terms, and the sample size is rather small, limiting the available degrees of freedom.

\subsection{Robustness Checks}

To ensure the robustness of our main findings, we carry out a number of additional estimations that are reported in Appendix B. First, in order to see how the spatial effects change with increasing distance, we estimate the SLX models using different distance weight matrices. Examples of results of the base model using $100 \mathrm{~km}$ and $150 \mathrm{~km}$ distance instead of $50 \mathrm{~km}$ are shown in Table 7. As we detected spatial effects for both the income terms and energy consumption for per capita $\mathrm{SO}_{\mathrm{X}}$ emissions in Sect. 5.2, we focus on differences to those estimates. Interestingly, while the nature of the direct effects does not change for any variable, the spatial effects tend to decrease with increasing distance. Specifically, the significant spatial spillovers of the per capita income terms found for $50 \mathrm{~km}$ distance in column (7), become insignificant from $100 \mathrm{~km}$ onwards. Compared to the $50 \mathrm{~km}$ estimate, the indirect spatial effect of energy consumption decreases at $100 \mathrm{~km}$ distance, and becomes insignificant at $150 \mathrm{~km}$. This supports our prior reasoning to analyze a rather short distance, so as to reveal spatial interactions for emissions with strong local effects.

Second, we base our model selection on the recent approach to compare spatial models with exogenous interactions $W X$ using Bayesian comparison methods (Halleck Vega and Elhorst 2015; LeSage 2014). When the classic popular selection strategies, that are based on maximum likelihood estimates, are used instead (Elhorst 2010; LeSage and Pace 2009), then for some analyzed specifications, the test statistics partly indicate that a spatial Durbin model could be the preferred model. This is particularly the case for estimations including only few control variables. Therefore, besides the Han-Phillips estimates of the parsimonious specification of the SLX model, Tables 8 and 9 report the corresponding maximum likelihood results of the SLX and spatial Durbin model. The latter model includes an additional spatially lagged dependent variable instead of the plain lagged dependent variable 
of the Han-Phillips estimator. As in the other robustness checks, the general shape of the EKC associated with the direct coefficients remains unchanged for both $\mathrm{SO}_{\mathrm{X}}$ and TSP emissions. However, for $\mathrm{SO}_{\mathrm{X}}$, the significant direct coefficients of the spatial Durbin model in column (21) become insignificant, when translating them into direct effects, considering also the significant coefficient of the spatially lagged dependent variable. While significant spatial spillovers are estimated for the income terms for the maximum likelihood estimates for $\mathrm{SO}_{\mathrm{X}}$ but not for the Han-Phillips estimates, the corresponding insignificant indirect spatial effects for TSP of the spatial Durbin model are similar to those of the Han-Phillips SLX model. Regarding the control variables, most importantly, the significant direct and indirect effects of energy consumption are robust across estimators and spatial models for $\mathrm{SO}_{\mathrm{X}}$ emissions. In contrast, for TSP, the significant indirect spatial effect of energy consumption in the Han-Phillips estimates in column (22) vanishes in the maximum likelihood estimates. Hence, although the direct effects tend to be rather similar for the main variables, no general tendency can be observed when the indirect effects match. This leaves some uncertainty, when past model selection strategies and an estimator, that only partly controls for simultaneity, are consulted as the benchmark.

Third, we estimate our models without spatial interactions using different panel estimators than the fixed effects estimator. Our intuitive first choice is the Han-Phillips estimator to specify differences to the spatial estimations. As can be seen in the examples of results in columns (25) to (28) in Table 10, the coefficients of the main determinants are very similar to the direct effect estimates in Tables 2 and 3. Even though several control variables are less significant for TSP, the most interesting difference to the spatial estimations are the significantly negative green growth binaries for both $\mathrm{SO}_{\mathrm{X}}$ and TSP, which we also detected in the fixed effects estimations. This supports our conjecture that the consideration of spatial interactions is decisive to obtain (unbiased) insignificant coefficients of the green growth binary, given the relevance of regional elements in the economic and environmental policies. Two-stage least squares (2SLS) and maximum likelihood are used as the second and third alternative estimators. In the former estimation, we also control for endogeneity by implementing an instrumental variable for income, that is based on a model from the endogenous growth literature (Mankiw et al. 1992) and has been applied in prior studies on the trade, growth and environment nexus (Frankel and Rose 2005; Hille and Lambernd 2020; Managi et al. 2009). ${ }^{25}$ The latter estimator is selected, because spatial econometric analyses have often considered maximum likelihood estimations. Similar to the Han-Phillips estimates without spatial interactions, the base specification results in columns (29) to (32) reveal the same nature of the income, population density, and energy consumption coefficients, paired with partly different estimates for the remaining control variables.

Fourth, apart from the lagged dependent variable, we analyze contemporaneous effects in our main models, following prior research on the growth-environment relationship (Balsalobre-Lorente et al. 2018; Cole et al. 2005; Park and Lee 2011). Nonetheless, the effect of various factors may be subject to a lag, such as the income-induced technique effect (Antweiler et al. 2001), innovation activity (Popp 2016), and government environmental policy (Meng and Huang 2018). To account for potential lagged effects of explanatory variables, we tested several alternative lag structures. As an example, Table 11 depicts the results

\footnotetext{
${ }^{25}$ Specifically, in the first-stage, per capita income is regressed on the base model as estimated in Mankiw et al. (1992), controlling for physical capital investments, population growth, and human capital. Following the related literature in the field, we also specify a panel structure, and include the capital intensity (Managi et al. 2009) and FDI inflows as a trade measure (Hille and Lambernd 2020).
} 
when we analyze per capita emissions as a moving average of the years $t$ and $t+1$ as well as $R \& D$ expenditures as a moving average of the years $t$ to $t-3$. Compared to columns (7) and (10) in Tables 2 and 3, the nature of both the direct and indirect effects of the income terms is fairly robust, which also holds for other estimated lag structures. By contrast, as expected, the estimated effects of the control variables are partly more dependent on the selected lag structure. For instance, when per capita emissions are in moving averages, i.e. potential lags are considered more generally, the direct effect of educational attainment persistently drives per capita $\mathrm{SO}_{\mathrm{X}}$ and TSP emissions, whereas the indirect effect of energy consumption is not significant anymore. In line with prior research (Popp 2016), our estimations of the lagged effects of $\mathrm{R} \& \mathrm{D}$ expenditures indicate that their cleanup effect on both $\mathrm{SO}_{\mathrm{X}}$ and TSP emissions increases over time, and in the case of $\mathrm{SO}_{\mathrm{X}}$, only becomes partly significant with a lag of three years.

Fifth, an intuitive related question, which may arise with regard to the time dimension, is if the emissions developed differently during the periods of the First and Second FiveYear Plan for Green Growth. Therefore, we include two green growth binaries in the estimations in columns (37) and (38) in Table 12. The binary for the First Five-Year Plan takes the value of 1 for the years 2009 to 2013, and the one for the Second Five-Year Plan is 1 from 2014 onwards. Similar to columns (8) and (11) in Tables 2 and 3, analyzing the whole green growth period with one binary, we find no significant changes of per capita emissions during the First Five-Year Plan. By contrast, the estimates suggest that province-level per capita $\mathrm{SO}_{\mathrm{X}}$ emissions have been significantly lower during the Second Five-Year Plan period, and per capita TSP emissions have been higher. Yet, one should keep in mind that our sample allows an ex-post analysis of the First Five-Year Plan period only. Data for the Second Five-Year Plan period is limited, and thus may not be representative. With regard to the other variables, the coefficients are mostly comparable with those in columns (8) and (11).

Sixth, airborne dust and biological combustion, which are particularly relevant for TSP emissions, have been included in the aggregate emission statistics since 2015 (NIER 2020). As it is not possible to exclude the additional sources from the province-level data, we tested the robustness of results to this statistical change by re-estimating our models using data until 2014 only. As can be seen in the example of results for TSP in column (39) in Table 12, the main findings remain unchanged. Compared to column (10) in Table 3, only the prior marginally significant direct effects of control variables are not significant anymore, which may however also stem from the reduced number of degrees of freedom. Hence, the change in emissions, because of the additional emission sources, appear to be mostly captured by the included fixed effects.

Last, a strand of literature has decomposed the environmental effects of economic growth (Antweiler et al. 2001; Grether et al. 2009; Levinson 2015). Inspired by Meng and Huang (2018) and Cole and Elliot (2003), we modify our parsimonious model to estimate decomposed growth effects in two simple models. That is, in one model estimated in columns (40) and (41) in Table 13, scale, technique, and composition effects are measured using per capita income, energy intensity, and the share of the secondary sector in the gross regional product, respectively. In a second model in columns (42) and (43), the joint scale and technique effect is reflected by per capita income, whereas the capital-labor ratio and trade intensity measure direct and trade-induced composition effects. ${ }^{26}$ In addition, we

\footnotetext{
${ }^{26}$ For consistency reasons, we keep the cubic income term in both models. To ensure that the expected sign of the technique effect elasticity is comparable with prior research, we multiply energy intensity by -1 in the first model. In the second model, we include a direct trade intensity term only, and hence do not
} 
Table 2 SLX model Han-Phillips estimations for $\mathrm{SO}_{\mathrm{X}}$

\begin{tabular}{|c|c|c|c|c|c|c|}
\hline \multirow[b]{2}{*}{ Variables } & \multicolumn{2}{|l|}{$\begin{array}{l}(7) \\
S O_{X} \\
\text { Base }\end{array}$} & \multicolumn{2}{|l|}{$\begin{array}{l}(8) \\
S O_{X} \\
\text { GG intercept }\end{array}$} & \multicolumn{2}{|c|}{$\begin{array}{l}\text { (9) } \\
S O_{X} \\
\text { GG slope \& intercept }\end{array}$} \\
\hline & $X^{\mathrm{a}}$ & $W X^{\mathrm{a}}$ & $X$ & $W X$ & $X$ & $W X$ \\
\hline $\ln (E)_{t-1}$ & $\begin{array}{l}0.755 * * * \\
(0.151)\end{array}$ & & $\begin{array}{l}0.676^{* * * *} \\
(0.147)\end{array}$ & & $\begin{array}{l}0.843 * * * \\
(0.150)\end{array}$ & \\
\hline$I N C$ & $\begin{array}{l}-0.404 * * * \\
(0.107)\end{array}$ & $\begin{array}{l}-0.328^{*} \\
(0.195)\end{array}$ & $\begin{array}{l}-0.402 * * * \\
(0.101)\end{array}$ & $\begin{array}{l}-0.280 \\
(0.182)\end{array}$ & $\begin{array}{l}-0.455^{* * * *} \\
(0.162)\end{array}$ & $\begin{array}{l}-0.470 \\
(0.409)\end{array}$ \\
\hline$I N C^{2}$ & $\begin{array}{l}0.010 * * * \\
(0.003)\end{array}$ & $\begin{array}{l}0.012 * \\
(0.007)\end{array}$ & $\begin{array}{l}0.009 * * * \\
(0.003)\end{array}$ & $\begin{array}{l}0.011^{*} \\
(0.006)\end{array}$ & $\begin{array}{l}0.011^{* *} \\
(0.005)\end{array}$ & $\begin{array}{l}0.017 \\
(0.016)\end{array}$ \\
\hline$I N C^{3}$ & $\begin{array}{l}-0.00008^{* * *} \\
(0.00003)\end{array}$ & $\begin{array}{l}-0.00014^{* *} \\
(0.00007)\end{array}$ & $\begin{array}{l}-0.00007^{* * *} \\
(0.00002)\end{array}$ & $\begin{array}{l}-0.00013^{*} \\
(0.00007)\end{array}$ & $\begin{array}{l}-0.00009 * * * \\
(0.00004)\end{array}$ & $\begin{array}{l}-0.00019 \\
(0.00020)\end{array}$ \\
\hline GreenGrowth & & & $\begin{array}{l}-0.036 \\
(0.077)\end{array}$ & $\begin{array}{l}-0.060 \\
(0.058)\end{array}$ & $\begin{array}{l}-0.319 \\
(1.197)\end{array}$ & $\begin{array}{l}-1.453 \\
(3.303)\end{array}$ \\
\hline GreenGrowth $\times I N C$ & & & & & $\begin{array}{l}0.033 \\
(0.122)\end{array}$ & $\begin{array}{l}0.167 \\
(0.398)\end{array}$ \\
\hline GreenGrowth $\times I N C^{2}$ & & & & & $\begin{array}{l}-0.001 \\
(0.004)\end{array}$ & $\begin{array}{l}-0.006 \\
(0.016)\end{array}$ \\
\hline GreenGrowth $\times I N C^{3}$ & & & & & $\begin{array}{l}0.00002 \\
(0.00004)\end{array}$ & $\begin{array}{l}0.00008 \\
(0.00020)\end{array}$ \\
\hline $\ln (P O P / A R E A)$ & $\begin{array}{l}-3.491 * * \\
(1.459)\end{array}$ & $\begin{array}{l}0.734 \\
(1.377)\end{array}$ & $\begin{array}{l}-3.340 * * \\
(1.307)\end{array}$ & $\begin{array}{l}0.780 \\
(1.215)\end{array}$ & $\begin{array}{l}-4.969^{* *} \\
(2.222)\end{array}$ & $\begin{array}{l}-1.087 \\
(2.165)\end{array}$ \\
\hline $\ln (E N U S E)$ & $\begin{array}{l}0.890 * * * \\
(0.256)\end{array}$ & $\begin{array}{l}0.766 * * \\
(0.344)\end{array}$ & $\begin{array}{l}0.905 * * * \\
(0.256)\end{array}$ & $\begin{array}{l}0.794 * * \\
(0.345)\end{array}$ & $\begin{array}{l}0.935 * * * \\
(0.256)\end{array}$ & $\begin{array}{l}0.782 * * \\
(0.355)\end{array}$ \\
\hline $\ln (C A R S)$ & $\begin{array}{l}-0.486 \\
(0.451)\end{array}$ & $\begin{array}{l}-0.429 \\
(0.454)\end{array}$ & $\begin{array}{l}-0.399 \\
(0.438)\end{array}$ & $\begin{array}{l}-0.300 \\
(0.446)\end{array}$ & $\begin{array}{l}-0.264 \\
(0.559)\end{array}$ & $\begin{array}{l}0.063 \\
(0.544)\end{array}$ \\
\hline $\ln (K / L)$ & $\begin{array}{l}0.270 \\
(0.404)\end{array}$ & $\begin{array}{l}-0.401 \\
(0.339)\end{array}$ & $\begin{array}{l}0.392 \\
(0.404)\end{array}$ & $\begin{array}{l}-0.279 \\
(0.334)\end{array}$ & $\begin{array}{l}0.173 \\
(0.450)\end{array}$ & $\begin{array}{l}-0.190 \\
(0.412)\end{array}$ \\
\hline $\ln (R \& D)$ & $\begin{array}{l}0.045 \\
(0.067)\end{array}$ & $\begin{array}{l}0.043 \\
(0.086)\end{array}$ & $\begin{array}{l}0.054 \\
(0.068)\end{array}$ & $\begin{array}{l}0.044 \\
(0.087)\end{array}$ & $\begin{array}{l}0.028 \\
(0.067)\end{array}$ & $\begin{array}{l}0.054 \\
(0.087)\end{array}$ \\
\hline $\ln (G O V)$ & $\begin{array}{l}0.124 \\
(0.207)\end{array}$ & $\begin{array}{l}-0.039 \\
(0.174)\end{array}$ & $\begin{array}{l}0.185 \\
(0.214)\end{array}$ & $\begin{array}{l}0.0156 \\
(0.177)\end{array}$ & $\begin{array}{l}0.111 \\
(0.221)\end{array}$ & $\begin{array}{l}0.0190 \\
(0.190)\end{array}$ \\
\hline $\ln (F D I)$ & $\begin{array}{l}0.000 \\
(0.008)\end{array}$ & $\begin{array}{l}0.003 \\
(0.012)\end{array}$ & $\begin{array}{l}0.000 \\
(0.008)\end{array}$ & $\begin{array}{l}0.003 \\
(0.012)\end{array}$ & $\begin{array}{l}0.000 \\
(0.008)\end{array}$ & $\begin{array}{l}0.006 \\
(0.012)\end{array}$ \\
\hline $\ln (E D U)$ & $\begin{array}{l}-0.129 \\
(1.443)\end{array}$ & $\begin{array}{l}-0.580 \\
(1.303)\end{array}$ & $\begin{array}{l}-0.277 \\
(1.429)\end{array}$ & $\begin{array}{l}-0.415 \\
(1.294)\end{array}$ & $\begin{array}{l}-0.705 \\
(1.565)\end{array}$ & $\begin{array}{l}-0.790 \\
(1.407)\end{array}$ \\
\hline Constant & $\begin{array}{l}5.183 \\
(4.091)\end{array}$ & & $\begin{array}{l}3.920 \\
(4.287)\end{array}$ & & $\begin{array}{l}6.093 * \\
(3.334)\end{array}$ & \\
\hline Observations & 256 & & 256 & & 256 & \\
\hline Log-likelihood & -53.48 & & -7.81 & & -114.59 & \\
\hline Wald test & $93.03 * * *$ & & $104.94 * * *$ & & $79.57 * * *$ & \\
\hline$F$-statistic & $4.04^{* * * *}$ & & $4.20 * * *$ & & $2.57 * * *$ & \\
\hline
\end{tabular}

$* * * p<0.01 ; * * p<0.05 ; * p<0.10$; robust standard errors are in parentheses

${ }^{a}$ While $X$ refers to the non-spatially weighted explanatory variables, $W X$ refers to the spatially weighted explanatory variables

Footnote 26 (continued)

specify the trade-induced composition effect for several sources of comparative advantage, because this is not our focus. 
add the green growth binary in the models to ensure that the insignificant coefficient estimates in the spatial model remain robust when the structure of the model is altered. We find that per capita $\mathrm{SO}_{\mathrm{X}}$ and TSP emissions are significantly increased by scale effects and decreased by technique effects. Overall, the scale effect at least offsets the cleanup through the technique effect. Growth- and trade-induced changes in the industrial structure do neither significantly increase nor reduce emissions. In the case of the first model, this may be explained by large variations in the average effect across provinces, as the positive values of the direct composition effect are larger than the corresponding scale effects. Strikingly, as in our original spatial model, we detect no evidence of significantly reduced per capita emissions following the launch of the green growth strategy, which again highlights the importance to control for spatial interactions. Similarly, the nature of the direct and indirect effects of the priorly included variables is fairly robust to the changes in the functional form.

\section{Conclusion and Policy Recommendations}

In the light of the relatively high air emission levels and the importance of regional aspects in the green growth strategy, we analyzed the effect of economic growth on $\mathrm{SO}_{\mathrm{X}}$ and TSP emissions in Korea, utilizing province-level data. Our study supplements prior research by testing for related changes induced by the National Strategy for Green Growth, providing spatial econometric evidence on spillovers to air emissions for a country that has rarely been analyzed regionally, and employing a more recently developed spatial estimator.

We find predominantly inverted $\mathrm{N}$-shaped EKCs for per capita $\mathrm{SO}_{\mathrm{X}}$ and TSP emissions. For $\mathrm{SO}_{\mathrm{X}}$, the growth effects are both direct and indirect through spillovers from nearby provinces. For TSP, the growth effects appear to be concentrated locally, i.e. only direct effects are estimated. As the inverted $\mathrm{N}$-curves initially decrease strongly with growing income, the main cleanup is realized with the mean income level. Yet, while the remaining $\mathrm{SO}_{\mathrm{X}}$ emissions are relatively low at higher income levels, a high income seems to be required until the relatively high remaining TSP emissions are abated. Even though the fixed effects estimations indicate that per capita $\mathrm{SO}_{\mathrm{X}}$ and TSP emissions have been significantly lower following the launch of the green growth strategy, the effects vanish for the spatial estimations. This indicates that the results may be biased when spatial interactions are not controlled for. We also find no convincing evidence that the regional economic growth path has become cleaner since 2009. Besides economic growth, population density and energy consumption are the main drivers of emission changes. While increases in population density directly reduce per capita emissions, decreased energy consumption tends to reduce per capita emissions both directly and indirectly through spatial effects on nearby provinces. The respective spatial spillovers decrease with increasing distance and become insignificant at $150 \mathrm{~km}$ distance. Moreover, in particular a higher educational attainment may help to directly reduce per capita TSP emissions.

Our results have important implications for policy makers. In view of the estimated shapes of the growth-emissions relationship, a naive thought could be to continue on the past growth path, and automatically reduce per capita emissions as income grows. Apart from uncertainties about future properties of economic growth, this may not be sufficient and take fairly long, given the relatively high pollution levels and recent regional economic growth rates. Hence, in order to become a forerunner in improving the quality of life, as proclaimed by the National Strategy for Green Growth, the growth path needs to be shifted 
Table 3 SLX model Han-Phillips estimations for TSP

\begin{tabular}{|c|c|c|c|c|c|c|}
\hline \multirow[b]{2}{*}{ Variables } & \multicolumn{2}{|l|}{$\begin{array}{l}T S P \\
\text { Base } \\
(10)\end{array}$} & \multicolumn{2}{|l|}{$\begin{array}{l}(11) \\
T S P \\
\text { GG intercept }\end{array}$} & \multicolumn{2}{|c|}{$\begin{array}{l}(12) \\
\text { TSP } \\
\text { GG slope \& intercept }\end{array}$} \\
\hline & $X^{\mathrm{a}}$ & $W X^{\mathrm{a}}$ & $X$ & $W X$ & $X$ & $W X$ \\
\hline $\ln (E)_{t-1}$ & $\begin{array}{l}0.917 * * * \\
(0.260)\end{array}$ & & $\begin{array}{l}0.904 * * * \\
(0.263)\end{array}$ & & $\begin{array}{l}1.107 * * * \\
(0.263)\end{array}$ & \\
\hline$I N C$ & $\begin{array}{l}-0.347 * * \\
(0.165)\end{array}$ & $\begin{array}{l}0.102 \\
(0.267)\end{array}$ & $\begin{array}{l}-0.376^{* *} \\
(0.168)\end{array}$ & $\begin{array}{l}0.068 \\
(0.272)\end{array}$ & $\begin{array}{l}-0.328 \\
(0.244)\end{array}$ & $\begin{array}{l}0.053 \\
(0.549)\end{array}$ \\
\hline$I N C^{2}$ & $\begin{array}{l}0.010^{* *} \\
(0.004)\end{array}$ & $\begin{array}{l}-0.001 \\
(0.009)\end{array}$ & $\begin{array}{l}0.011^{* *} \\
(0.004)\end{array}$ & $\begin{array}{l}0.000 \\
(0.009)\end{array}$ & $\begin{array}{l}0.010 \\
(0.007)\end{array}$ & $\begin{array}{l}0.000 \\
(0.022)\end{array}$ \\
\hline$I N C^{3}$ & $\begin{array}{l}-0.00010^{* * *} \\
(0.00004)\end{array}$ & $\begin{array}{l}-0.00003 \\
(0.00010)\end{array}$ & $\begin{array}{l}-0.00011^{* * * *} \\
(0.00004)\end{array}$ & $\begin{array}{l}-0.00004 \\
(0.00010)\end{array}$ & $\begin{array}{l}-0.00009 \\
(0.00006)\end{array}$ & $\begin{array}{l}-0.00002 \\
(0.00029)\end{array}$ \\
\hline GreenGrowth & & & $\begin{array}{l}-0.116 \\
(0.153)\end{array}$ & $\begin{array}{l}0.009 \\
(0.119)\end{array}$ & $\begin{array}{l}2.953 \\
(2.225)\end{array}$ & $\begin{array}{l}5.441 \\
(5.786)\end{array}$ \\
\hline GreenGrowth $\times I N C$ & & & & & $\begin{array}{l}-0.279 \\
(0.225)\end{array}$ & $\begin{array}{l}-0.529 \\
(0.693)\end{array}$ \\
\hline GreenGrowth $\times I N C^{2}$ & & & & & $\begin{array}{l}0.007 \\
(0.007)\end{array}$ & $\begin{array}{l}0.017 \\
(0.027)\end{array}$ \\
\hline GreenGrowth $\times I N C^{3}$ & & & & & $\begin{array}{l}-0.00006 \\
(0.00007)\end{array}$ & $\begin{array}{l}-0.00019 \\
(0.00035)\end{array}$ \\
\hline $\ln (P O P / A R E A)$ & $\begin{array}{l}-5.011^{* * *} \\
(1.621)\end{array}$ & $\begin{array}{l}-0.909 \\
(1.478)\end{array}$ & $\begin{array}{l}-5.002^{* * *} \\
(1.628)\end{array}$ & $\begin{array}{l}-0.894 \\
(1.487)\end{array}$ & $\begin{array}{l}-5.207 * * * \\
(1.986)\end{array}$ & $\begin{array}{l}-0.799 \\
(1.794)\end{array}$ \\
\hline $\ln (E N U S E)$ & $\begin{array}{l}3.263 * * * \\
(0.480)\end{array}$ & $\begin{array}{l}2.017 * * * \\
(0.610)\end{array}$ & $\begin{array}{l}3.246^{* * * *} \\
(0.483)\end{array}$ & $\begin{array}{l}1.988 * * * \\
(0.616)\end{array}$ & $\begin{array}{l}3.271 * * * \\
(0.536)\end{array}$ & $\begin{array}{l}2.233^{* * * *} \\
(0.708)\end{array}$ \\
\hline $\ln (C A R S)$ & $\begin{array}{l}-0.244 \\
(0.976)\end{array}$ & $\begin{array}{l}-1.313 \\
(0.925)\end{array}$ & $\begin{array}{l}-0.218 \\
(0.980)\end{array}$ & $\begin{array}{l}-1.222 \\
(0.932)\end{array}$ & $\begin{array}{l}-0.089 \\
(1.182)\end{array}$ & $\begin{array}{l}-1.221 \\
(1.062)\end{array}$ \\
\hline $\ln (K / L)$ & $\begin{array}{l}1.449 * \\
(0.744)\end{array}$ & $\begin{array}{l}0.234 \\
(0.657)\end{array}$ & $\begin{array}{l}1.552^{* *} \\
(0.754)\end{array}$ & $\begin{array}{l}0.288 \\
(0.664)\end{array}$ & $\begin{array}{l}1.360 \\
(0.853)\end{array}$ & $\begin{array}{l}0.176 \\
(0.746)\end{array}$ \\
\hline $\ln (R \& D)$ & $\begin{array}{l}-0.278^{*} \\
(0.145)\end{array}$ & $\begin{array}{l}-0.208 \\
(0.176)\end{array}$ & $\begin{array}{l}-0.264 * \\
(0.146)\end{array}$ & $\begin{array}{l}-0.194 \\
(0.179)\end{array}$ & $\begin{array}{l}-0.257 \\
(0.156)\end{array}$ & $\begin{array}{l}-0.149 \\
(0.198)\end{array}$ \\
\hline $\ln (G O V)$ & $\begin{array}{l}0.212 \\
(0.427)\end{array}$ & $\begin{array}{l}-0.217 \\
(0.367)\end{array}$ & $\begin{array}{l}0.336 \\
(0.455)\end{array}$ & $\begin{array}{l}-0.192 \\
(0.385)\end{array}$ & $\begin{array}{l}0.206 \\
(0.495)\end{array}$ & $\begin{array}{l}-0.187 \\
(0.417)\end{array}$ \\
\hline $\ln (F D I)$ & $\begin{array}{l}-0.008 \\
(0.018)\end{array}$ & $\begin{array}{l}0.032 \\
(0.027)\end{array}$ & $\begin{array}{l}-0.007 \\
(0.018)\end{array}$ & $\begin{array}{l}0.032 \\
(0.027)\end{array}$ & $\begin{array}{l}-0.009 \\
(0.019)\end{array}$ & $\begin{array}{l}0.037 \\
(0.029)\end{array}$ \\
\hline $\ln (E D U)$ & $\begin{array}{l}-5.823^{*} \\
(3.053)\end{array}$ & $\begin{array}{l}1.061 \\
(2.708)\end{array}$ & $\begin{array}{l}-5.909 * \\
(3.069)\end{array}$ & $\begin{array}{l}0.807 \\
(2.730)\end{array}$ & $\begin{array}{l}-6.608^{*} \\
(3.568)\end{array}$ & $\begin{array}{l}0.842 \\
(3.081)\end{array}$ \\
\hline Constant & $\begin{array}{l}-24.57 \\
(24.44)\end{array}$ & & $\begin{array}{l}-21.59 \\
(24.70)\end{array}$ & & $\begin{array}{l}-15.56 \\
(20.16)\end{array}$ & \\
\hline Observations & 256 & & 256 & & 256 & \\
\hline Log-likelihood & -303.28 & & -302.61 & & -342.04 & \\
\hline Wald test & $160.39 * * *$ & & $159.86^{* * *}$ & & $141.14 * * *$ & \\
\hline$F$-statistic & $6.97 * * *$ & & $6.40 * * *$ & & $4.55^{* * * *}$ & \\
\hline
\end{tabular}

$* * * p<0.01 ; * * p<0.05 ; * p<0.10$; robust standard errors are in parentheses

${ }^{\text {a }}$ While $X$ refers to the non-spatially weighted explanatory variables, $W X$ refers to the spatially weighted explanatory variables 
and become greener. This can potentially be achieved through changes in the technique and composition effects. That is, targeted environmental regulations may facilitate the adoption of cleaner technologies, and the desired structural change towards creative and knowledgeintensive sectors may lower the dependence on capital-intensive industries. The estimates for TSP, which are possibly also relevant for other emerging pollutants, seem to support this picture. Accordingly, investments in R\&D and in particular in a higher educational attainment, which provide leverage to move towards an innovative and creative economy, are regarded as supportive policy handles. Moreover, implemented policy instruments, such as certificate trading systems, target the reduction of air pollution, where abatement costs are lowest, and thus can be effective tools. However, considering their insignificant influence on local air emissions, the initiatives of the green growth strategy need to be intensified and further substantiated with concrete action plans for the near future. For instance, this regards energy consumption as a main driver of emission increases. On the one hand, the share of renewable energies in the energy mix, which was recently only 5\% (KEEI 2018), needs to be increased through ambitious policy targets and regulatory support. On the other hand, South Korea should continue reducing its high energy intensity, e.g. by improving the energy efficiency of important energy consumers, such as heavy industries, the transportation sector, and households. In this context, the focus on green cluster initiatives, the funding of innovative entities, and public infrastructure investments target promising levers. As energy consumption spillovers from nearby provinces influence air emissions, nationwide actions are required. Through targeted policies and industrial upgrades, these actions may also represent an effective tool to support underdeveloped regions, besides improving their environmental quality.

Future research focusing on regional aspects may, subject to data availability, supplement our analysis in several ways. Firstly, in order to provide a comprehensive evaluation of the implemented initiatives and test for related improvements in other dimensions, the remaining main objectives of the National Strategy for Green Growth need to be analyzed. For instance, this regards the growth effects on emissions with global effects, such as $\mathrm{CO}_{2}$, or on the targeted transition of the energy system. In this context, an interesting recent analysis is Hille and Lambernd (2020), who focus on the role of technological change for energy consumption intensities of Korean provinces. Secondly, our conclusions are limited to the aggregate provincial level, i.e. our effects represent average values for the regional economies and thus cannot be specified for individual sectors. More disaggregated regional data on the sectoral, firm, or plant level may help to both take into account regional aspects of the green growth strategy and reveal detailed changes in the regulated entities. Thirdly, we analyze a sample of 18 years, of which eight years fall into the green growth strategy period. However, it may take some time until government initiatives and regulation translate into productivity and environmental quality improvements, because of the lengthy innovation process and lagged adoption of commercialized technologies (Yang et al. 2012; Popp 2016).

\section{Appendix A-Overviews}

See Fig. 2, Tables 4 and 5. 


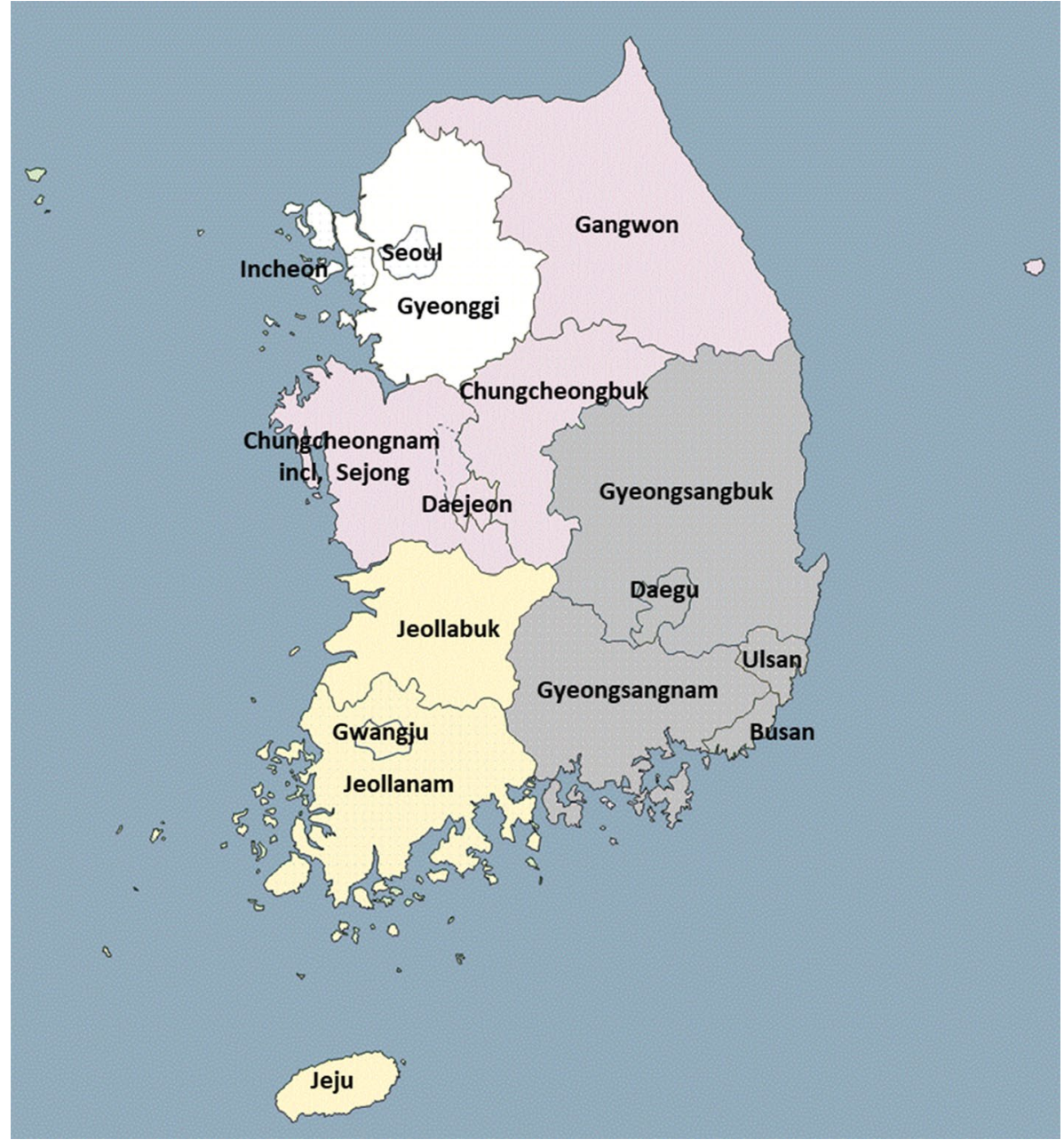

Fig. 2 Korean provinces 


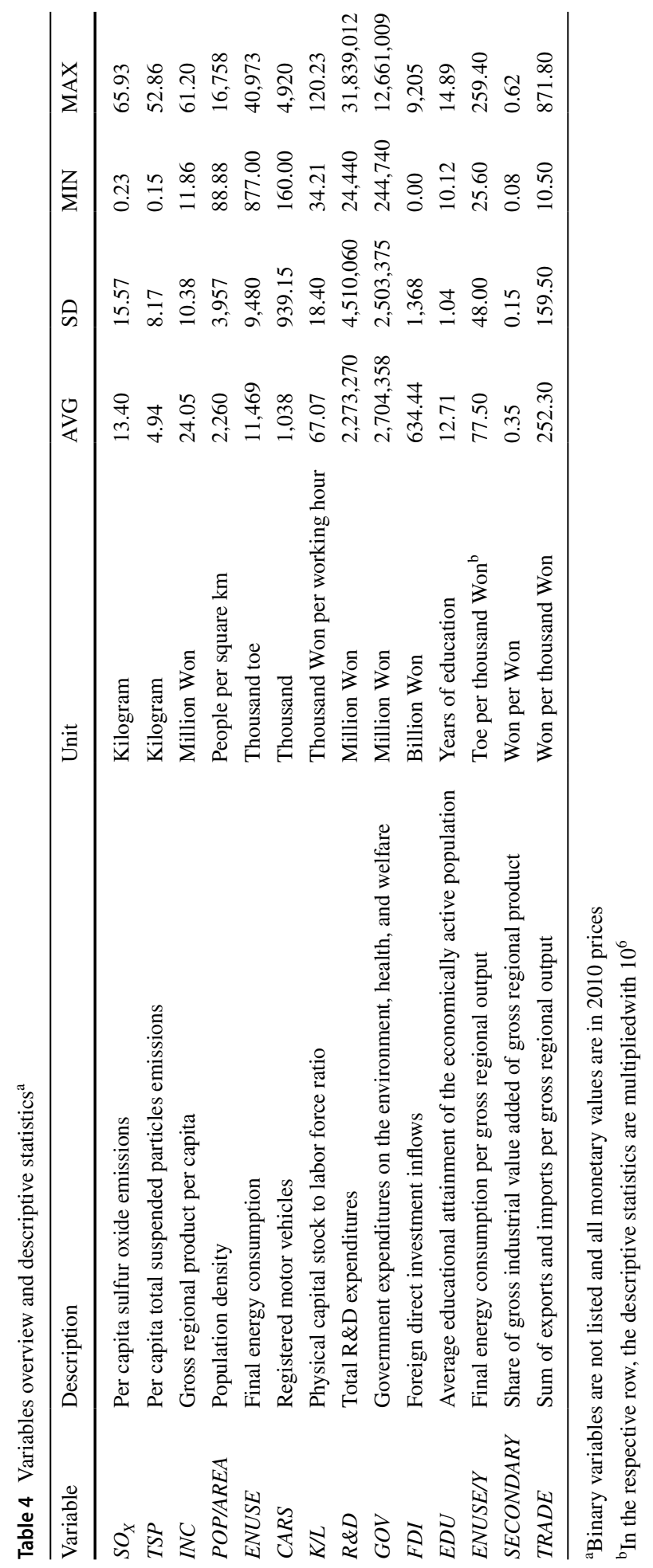


Table 5 Moran's I and LM tests

\begin{tabular}{|c|c|c|c|}
\hline & \multicolumn{3}{|c|}{ Threshold distance } \\
\hline & $50 \mathrm{~km}$ & $100 \mathrm{~km}$ & $150 \mathrm{~km}$ \\
\hline \multicolumn{4}{|c|}{ Spatial lag and error tests } \\
\hline \multicolumn{4}{|l|}{ For $S O_{X}$} \\
\hline Robust LM Lag & 0.067 & 0.002 & 0.222 \\
\hline Robust LM Error & $4.412 * *$ & 1.242 & $12.54 * * *$ \\
\hline Moran's I (Error) & $2.115^{* *}$ & 0.465 & 0.733 \\
\hline \multicolumn{4}{|l|}{ For TSP } \\
\hline Robust LM Lag & 0.122 & 0.048 & 0.371 \\
\hline Robust LM Error & $20.93 * * *$ & $56.89^{* * *}$ & $106.87 * * *$ \\
\hline Moran's I (Error) & $6.890 * * *$ & $3.700 * * *$ & $2.547 * *$ \\
\hline \multicolumn{4}{|l|}{ Moran's I } \\
\hline$S O_{X}$ & $0.443 * * *$ & $0.131 * * *$ & $0.095 * * *$ \\
\hline$T S P$ & $0.204 * * *$ & $0.056^{* * *}$ & 0.009 \\
\hline$I N C$ & $0.341 * * *$ & $0.046 * * *$ & $0.074 * * *$ \\
\hline POP/AREA & $0.555 * * *$ & $0.314 * * *$ & $0.063 * * *$ \\
\hline ENUSE & $0.457 * * *$ & $0.065^{* * *}$ & $0.106^{* * *}$ \\
\hline CARS & $0.777 * * *$ & $0.364 * * *$ & $0.145^{* * *}$ \\
\hline$K / L$ & $0.196 * * *$ & -0.001 & $0.022 * * *$ \\
\hline$R \& D$ & $0.636 * * *$ & $0.171 * * *$ & $0.134 * * *$ \\
\hline GOV & $0.570 * * *$ & $0.340 * * *$ & $0.128 * * *$ \\
\hline$F D I$ & $0.424 * * *$ & $0.334 * * *$ & $0.120 * * *$ \\
\hline$E D U$ & $0.407 * * *$ & $0.099 * * *$ & $0.035 * * *$ \\
\hline
\end{tabular}

$* * * p<0.01 ; * * p<0.05 ; * p<0.10$

\section{Appendix B - Additional Estimations}

See Fig. 3, Tables 6, 7, 8, 9, 10, 11, 12 and 13.
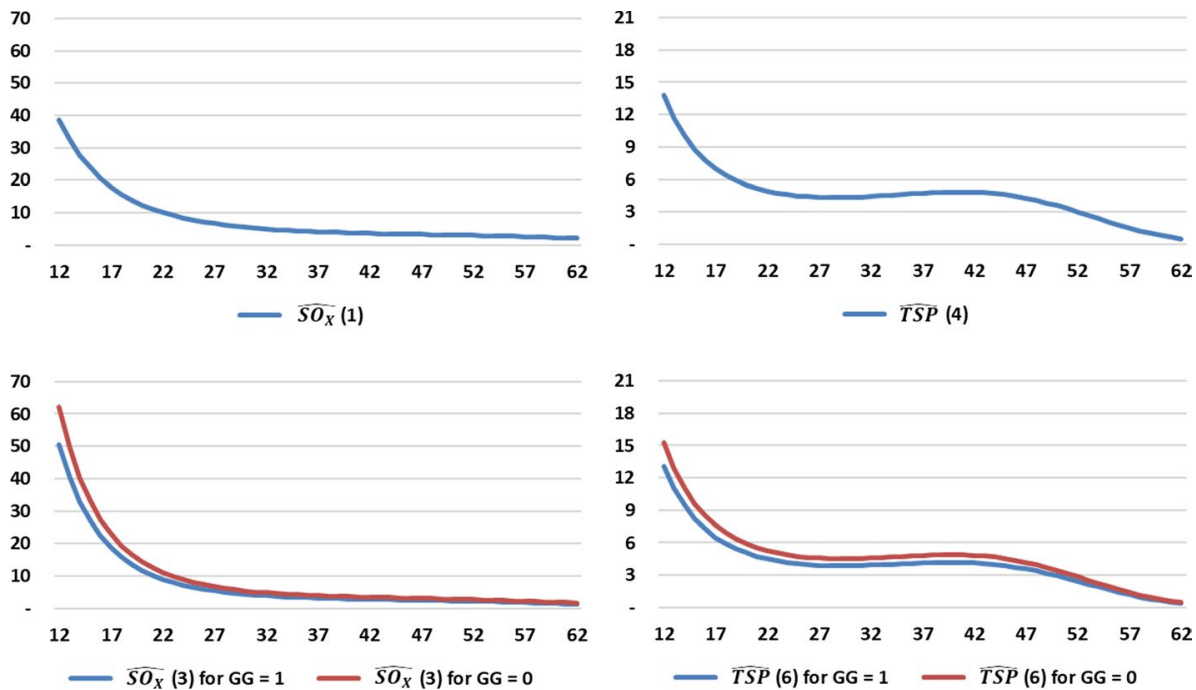

Fig. 3 Estimated EKCs at the median based on the results in columns (1), (3), (4), and (6) ${ }^{\text {a }}{ }^{\text {a }}$ While the $\mathrm{y}$-axes display per capita emissions in kilograms, the $\mathrm{x}$-axes show the per capita gross regional product in million Won 2010 prices 
Table 6 Estimations with linear and squared income terms only

\begin{tabular}{|c|c|c|c|c|c|c|c|c|}
\hline \multirow[b]{2}{*}{ Variables } & \multicolumn{2}{|c|}{$\begin{array}{l}(13) \\
S O_{X} \\
\text { Base_Only INC }\end{array}$} & \multicolumn{2}{|c|}{$\begin{array}{l}(14) \\
S O_{X} \\
\text { Base-Only INC \& INC }\end{array}$} & \multicolumn{2}{|c|}{$\begin{array}{l}(15) \\
T S P \\
\text { Base-Only INC }\end{array}$} & \multicolumn{2}{|c|}{$\begin{array}{l}(16) \\
T S P \\
\text { Base-Only INC \& } \\
I N C^{2}\end{array}$} \\
\hline & $X^{\mathrm{a}}$ & $W X^{\mathrm{a}}$ & $X$ & $W X$ & $X$ & $W X$ & $X$ & $W X$ \\
\hline $\ln (E)_{t-1}$ & $\begin{array}{l}0.570^{* * *} \\
(0.132)\end{array}$ & & $\begin{array}{l}0.566 * * * \\
(0.107)\end{array}$ & & $\begin{array}{l}0.913 * * * \\
(0.251)\end{array}$ & & $\begin{array}{l}1.035 * * * \\
(0.243)\end{array}$ & \\
\hline$I N C$ & $\begin{array}{l}-0.030^{*} \\
(0.017)\end{array}$ & $\begin{array}{l}-0.007 \\
(0.018)\end{array}$ & $\begin{array}{l}-0.120^{* * *} \\
(0.037)\end{array}$ & $\begin{array}{l}0.095 * * \\
(0.045)\end{array}$ & $\begin{array}{l}-0.028 \\
(0.028)\end{array}$ & $\begin{array}{l}-0.078^{* *} \\
(0.032)\end{array}$ & $\begin{array}{l}0.051 \\
(0.069)\end{array}$ & $\begin{array}{l}0.144 \\
(0.103)\end{array}$ \\
\hline$I N C^{2}$ & & & $\begin{array}{l}0.001 * * \\
(0.000)\end{array}$ & $\begin{array}{l}-0.002 * * \\
(0.001)\end{array}$ & & & $\begin{array}{l}-0.001 \\
(0.001)\end{array}$ & $\begin{array}{l}-0.004^{* *} \\
(0.001)\end{array}$ \\
\hline $\begin{array}{r}\ln (P O P / \\
A R E A)\end{array}$ & $\begin{array}{l}-2.113^{* *} \\
(1.053)\end{array}$ & $(0.973)$ & $\begin{array}{l}-2.603 * * \\
(1.077)\end{array}$ & $(0.957)$ & $\begin{array}{l}-5.218 * * * \\
(1.613)\end{array}$ & $\begin{array}{l}-1.035 \\
(1.472)\end{array}$ & $\begin{array}{l}-5.462 * * * \\
(1.857)\end{array}$ & $\begin{array}{l}-1.040 \\
(1.677)\end{array}$ \\
\hline $\ln (E N U S E)$ & $\begin{array}{l}1.269 * * * \\
(0.258)\end{array}$ & $\begin{array}{l}0.340 \\
(0.326)\end{array}$ & $\begin{array}{l}1.168 * * * \\
(0.255)\end{array}$ & $\begin{array}{l}0.738 * * \\
(0.354)\end{array}$ & $\begin{array}{l}3.564 * * * \\
(0.480)\end{array}$ & $\begin{array}{l}1.427 * * \\
(0.567)\end{array}$ & $\begin{array}{l}3.535 * * * \\
(0.515)\end{array}$ & $\begin{array}{l}2.087 * * * \\
(0.637)\end{array}$ \\
\hline $\ln (C A R S)$ & $\begin{array}{l}-0.920^{* *} \\
(0.403)\end{array}$ & $\begin{array}{l}-0.215 \\
(0.419)\end{array}$ & $\begin{array}{l}-0.692 * \\
(0.408)\end{array}$ & $\begin{array}{l}-0.369 \\
(0.424)\end{array}$ & $\begin{array}{l}-0.417 \\
(0.909)\end{array}$ & $\begin{array}{l}-0.055 \\
(0.767)\end{array}$ & $\begin{array}{l}-0.922 \\
(1.024)\end{array}$ & $\begin{array}{l}-1.386 \\
(0.995)\end{array}$ \\
\hline $\ln (K / L)$ & $\begin{array}{l}0.345 \\
(0.401)\end{array}$ & $\begin{array}{l}-0.202 \\
(0.323)\end{array}$ & $\begin{array}{l}0.342 \\
(0.392)\end{array}$ & $\begin{array}{l}-0.228 \\
(0.319)\end{array}$ & $\begin{array}{l}1.823 * * \\
(0.742)\end{array}$ & $\begin{array}{l}0.226 \\
(0.649)\end{array}$ & $\begin{array}{l}1.340 \\
(0.815)\end{array}$ & $\begin{array}{l}0.555 \\
(0.688)\end{array}$ \\
\hline $\ln (R \& D)$ & $\begin{array}{l}0.004 \\
(0.071)\end{array}$ & $\begin{array}{l}0.040 \\
(0.090)\end{array}$ & $\begin{array}{l}0.028 \\
(0.071)\end{array}$ & $\begin{array}{l}-0.011 \\
(0.092)\end{array}$ & $\begin{array}{l}-0.267^{*} \\
(0.145)\end{array}$ & $\begin{array}{l}-0.071 \\
(0.173)\end{array}$ & $\begin{array}{l}-0.325^{* *} \\
(0.150)\end{array}$ & $\begin{array}{l}-0.206 \\
(0.187)\end{array}$ \\
\hline $\ln (G O V)$ & $\begin{array}{l}-0.047 \\
(0.205)\end{array}$ & $\begin{array}{l}0.048 \\
(0.175)\end{array}$ & $\begin{array}{l}0.114 \\
(0.206)\end{array}$ & $\begin{array}{l}0.001 \\
(0.172)\end{array}$ & $\begin{array}{l}-0.302 \\
(0.406)\end{array}$ & $\begin{array}{l}0.205 \\
(0.359)\end{array}$ & $\begin{array}{l}-0.069 \\
(0.446)\end{array}$ & $\begin{array}{l}0.033 \\
(0.380)\end{array}$ \\
\hline $\ln (F D I)$ & $\begin{array}{l}0.002 \\
(0.008)\end{array}$ & $\begin{array}{l}0.003 \\
(0.013)\end{array}$ & $\begin{array}{l}-0.001 \\
(0.008)\end{array}$ & $\begin{array}{l}0.004 \\
(0.013)\end{array}$ & $\begin{array}{l}-0.010 \\
(0.018)\end{array}$ & $\begin{array}{l}0.035 \\
(0.028)\end{array}$ & $\begin{array}{l}-0.012 \\
(0.018)\end{array}$ & $\begin{array}{l}0.033 \\
(0.028)\end{array}$ \\
\hline $\ln (E D U)$ & $\begin{array}{l}-0.060 \\
(1.462)\end{array}$ & $\begin{array}{l}-1.159 \\
(1.326)\end{array}$ & $\begin{array}{l}-0.204 \\
(1.432)\end{array}$ & $\begin{array}{l}-0.673 \\
(1.311)\end{array}$ & $\begin{array}{l}-6.285^{* *} \\
(3.082)\end{array}$ & $\begin{array}{l}1.065 \\
(2.752)\end{array}$ & $\begin{array}{l}-6.411 * \\
(3.297)\end{array}$ & $\begin{array}{l}1.561 \\
(2.918)\end{array}$ \\
\hline Constant & $\begin{array}{l}0.393 \\
(4.547)\end{array}$ & & $\begin{array}{l}0.323 \\
(4.664)\end{array}$ & & $\begin{array}{l}-20.45 \\
(25.80)\end{array}$ & & $\begin{array}{l}-20.55 \\
(20.62)\end{array}$ & \\
\hline $\begin{array}{l}\text { Observa- } \\
\text { tions }\end{array}$ & 256 & & 256 & & 256 & & 256 & \\
\hline $\begin{array}{l}\text { Log-likeli- } \\
\text { hood }\end{array}$ & 50.87 & & 57.80 & & -289.59 & & -323.02 & \\
\hline Wald test & $100.93 * * *$ & & $126.88^{* * * *}$ & & $137.24 * * *$ & & $135.47 * * *$ & \\
\hline$F$-statistic & $5.31 * * *$ & & $6.04 * * *$ & & $7.22 * * *$ & & $6.45^{* * *}$ & \\
\hline
\end{tabular}

$* * * p<0.01 ; * * p<0.05 ; * p<0.10$; robust standard errors are in parentheses

${ }^{a}$ While $X$ refers to the non-spatially weighted explanatory variables, $W X$ refers to the spatially weighted explanatory variables 
Table 7 Robustness tests using different distances for the spatial weight matrix

\begin{tabular}{|c|c|c|c|c|c|c|}
\hline \multirow[b]{2}{*}{ Variables } & \multicolumn{2}{|l|}{$\begin{array}{l}(7) \\
S O_{X} \\
\text { Base-50 km }\end{array}$} & \multicolumn{2}{|c|}{$\begin{array}{l}(17) \\
S O_{X} \\
\text { Base-100 km }\end{array}$} & \multicolumn{2}{|l|}{$\begin{array}{l}(18) \\
S O_{X} \\
\text { Base-150 km }\end{array}$} \\
\hline & $X^{\mathrm{a}}$ & $W X^{\mathrm{a}}$ & $X$ & $W X$ & $X$ & $W X$ \\
\hline $\ln (E)_{t-1}$ & $\begin{array}{l}0.755 * * * \\
(0.151)\end{array}$ & & $\begin{array}{l}0.793 * * * \\
(0.126)\end{array}$ & & $\begin{array}{l}0.709 * * * \\
(0.132)\end{array}$ & \\
\hline$I N C$ & $\begin{array}{l}-0.404 * * * \\
(0.107)\end{array}$ & $\begin{array}{l}-0.328^{*} \\
(0.195)\end{array}$ & $\begin{array}{l}-0.343 * * * \\
(0.121)\end{array}$ & $\begin{array}{l}-0.017 \\
(0.082)\end{array}$ & $\begin{array}{l}-0.356 * * * \\
(0.111)\end{array}$ & $\begin{array}{l}-0.001 \\
(0.058)\end{array}$ \\
\hline$I N C^{2}$ & $\begin{array}{l}0.010 * * * \\
(0.003)\end{array}$ & $\begin{array}{l}0.012 * \\
(0.007)\end{array}$ & $\begin{array}{l}0.008 * * \\
(0.003)\end{array}$ & $\begin{array}{l}0.001 \\
(0.002)\end{array}$ & $\begin{array}{l}0.008 * * * \\
(0.003)\end{array}$ & $\begin{array}{l}0.000 \\
(0.002)\end{array}$ \\
\hline$I N C^{3}$ & $\begin{array}{l}-0.00008^{* * * *} \\
(0.00003)\end{array}$ & $\begin{array}{l}-0.00014^{* *} \\
(0.00007)\end{array}$ & $\begin{array}{l}-0.00006^{* * *} \\
(0.00003)\end{array}$ & $\begin{array}{l}-0.00001 \\
(0.00002)\end{array}$ & $\begin{array}{l}-0.00006^{* * *} \\
(0.00002)\end{array}$ & $\begin{array}{l}-0.00001 \\
(0.00001)\end{array}$ \\
\hline $\ln (P O P / A R E A)$ & $\begin{array}{l}-3.491 * * \\
(1.459)\end{array}$ & $\begin{array}{l}0.734 \\
(1.377)\end{array}$ & $\begin{array}{l}-3.436^{*} \\
(1.786)\end{array}$ & $\begin{array}{l}-1.467 \\
(1.087)\end{array}$ & $\begin{array}{l}-3.896^{* * * *} \\
(1.384)\end{array}$ & $\begin{array}{l}-0.288 \\
(0.667)\end{array}$ \\
\hline $\ln (E N U S E)$ & $\begin{array}{l}0.890 * * * \\
(0.256)\end{array}$ & $\begin{array}{l}0.766 * * \\
(0.344)\end{array}$ & $\begin{array}{l}0.937 * * * \\
(0.250)\end{array}$ & $\begin{array}{l}0.601 * * * \\
(0.201)\end{array}$ & $\begin{array}{l}0.936 * * * \\
(0.256)\end{array}$ & $\begin{array}{l}0.205 \\
(0.139)\end{array}$ \\
\hline $\ln (C A R S)$ & $\begin{array}{l}-0.486 \\
(0.451)\end{array}$ & $\begin{array}{l}-0.429 \\
(0.454)\end{array}$ & $\begin{array}{l}-0.597 \\
(0.493)\end{array}$ & $\begin{array}{l}-0.169 \\
(0.314)\end{array}$ & $\begin{array}{l}-0.309 \\
(0.461)\end{array}$ & $\begin{array}{l}-0.295 \\
(0.196)\end{array}$ \\
\hline $\ln (K / L)$ & $\begin{array}{l}0.270 \\
(0.404)\end{array}$ & $\begin{array}{l}-0.401 \\
(0.339)\end{array}$ & $\begin{array}{l}0.521 \\
(0.446)\end{array}$ & $\begin{array}{l}-0.249 \\
(0.190)\end{array}$ & $\begin{array}{l}0.303 \\
(0.456)\end{array}$ & $\begin{array}{l}-0.054 \\
(0.103)\end{array}$ \\
\hline $\ln (R \& D)$ & $\begin{array}{l}0.045 \\
(0.067)\end{array}$ & $\begin{array}{l}0.043 \\
(0.086)\end{array}$ & $\begin{array}{l}0.036 \\
(0.066)\end{array}$ & $\begin{array}{l}0.050 \\
(0.043)\end{array}$ & $\begin{array}{l}0.054 \\
(0.067)\end{array}$ & $\begin{array}{l}0.000 \\
(0.034)\end{array}$ \\
\hline $\ln (G O V)$ & $\begin{array}{l}0.124 \\
(0.207)\end{array}$ & $\begin{array}{l}-0.039 \\
(0.174)\end{array}$ & $\begin{array}{l}-0.103 \\
(0.238)\end{array}$ & $\begin{array}{l}0.129 \\
(0.098)\end{array}$ & $\begin{array}{l}-0.074 \\
(0.243)\end{array}$ & $\begin{array}{l}0.086 \\
(0.054)\end{array}$ \\
\hline $\ln (F D I)$ & $\begin{array}{l}0.000 \\
(0.008)\end{array}$ & $\begin{array}{l}0.003 \\
(0.012)\end{array}$ & $\begin{array}{l}0.001 \\
(0.008)\end{array}$ & $\begin{array}{l}0.005 \\
(0.006)\end{array}$ & $\begin{array}{l}0.001 \\
(0.008)\end{array}$ & $\begin{array}{l}-0.002 \\
(0.005)\end{array}$ \\
\hline $\ln (E D U)$ & $\begin{array}{l}-0.129 \\
(1.443)\end{array}$ & $\begin{array}{l}-0.580 \\
(1.303)\end{array}$ & $\begin{array}{l}-0.345 \\
(1.553)\end{array}$ & $\begin{array}{l}0.348 \\
(0.776)\end{array}$ & $\begin{array}{l}-0.320 \\
(1.581)\end{array}$ & $\begin{array}{l}0.239 \\
(0.462)\end{array}$ \\
\hline Constant & $\begin{array}{l}5.183 \\
(4.091)\end{array}$ & & $\begin{array}{l}6.875 \\
(4.427)\end{array}$ & & $\begin{array}{l}8.054 \\
(7.073)\end{array}$ & \\
\hline Observations & 256 & & 256 & & 256 & \\
\hline Log- likelihood & -53.48 & & -35.88 & & -17.88 & \\
\hline Wald test & $93.03 * * *$ & & $95.91 * * *$ & & $96.93 * * *$ & \\
\hline$F$ - statistic & $4.04 * * *$ & & $4.17 * * *$ & & $4.21 * * *$ & \\
\hline
\end{tabular}

$* * * p<0.01 ; * * p<0.05 ; * p<0.10$; robust standard errors are in parentheses; results are obtained using the Han-Phillips estimator

${ }^{\text {a }}$ While $X$ refers to the non-spatially weighted explanatory variables, $W X$ refers to the spatially weighted explanatory variables 


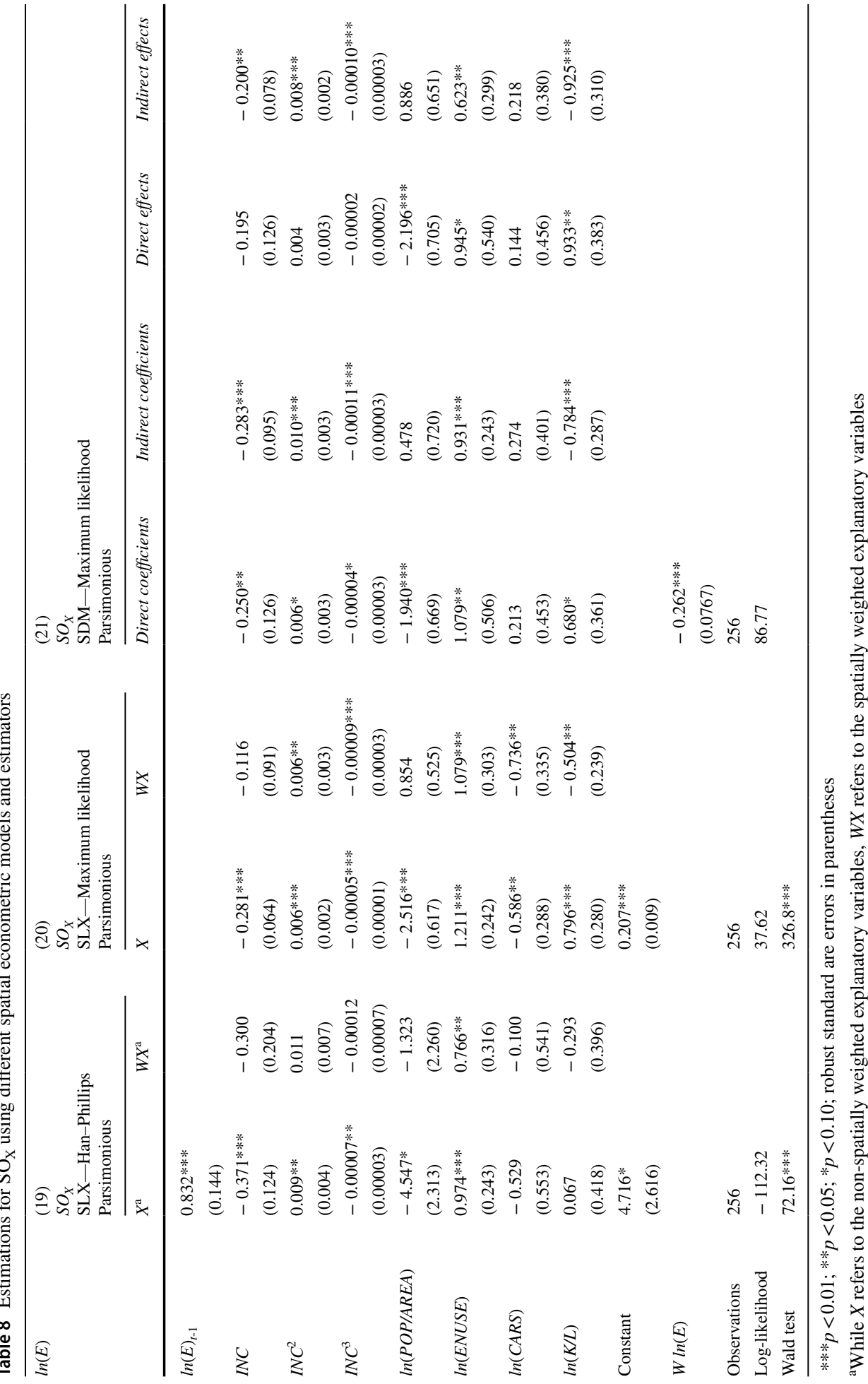




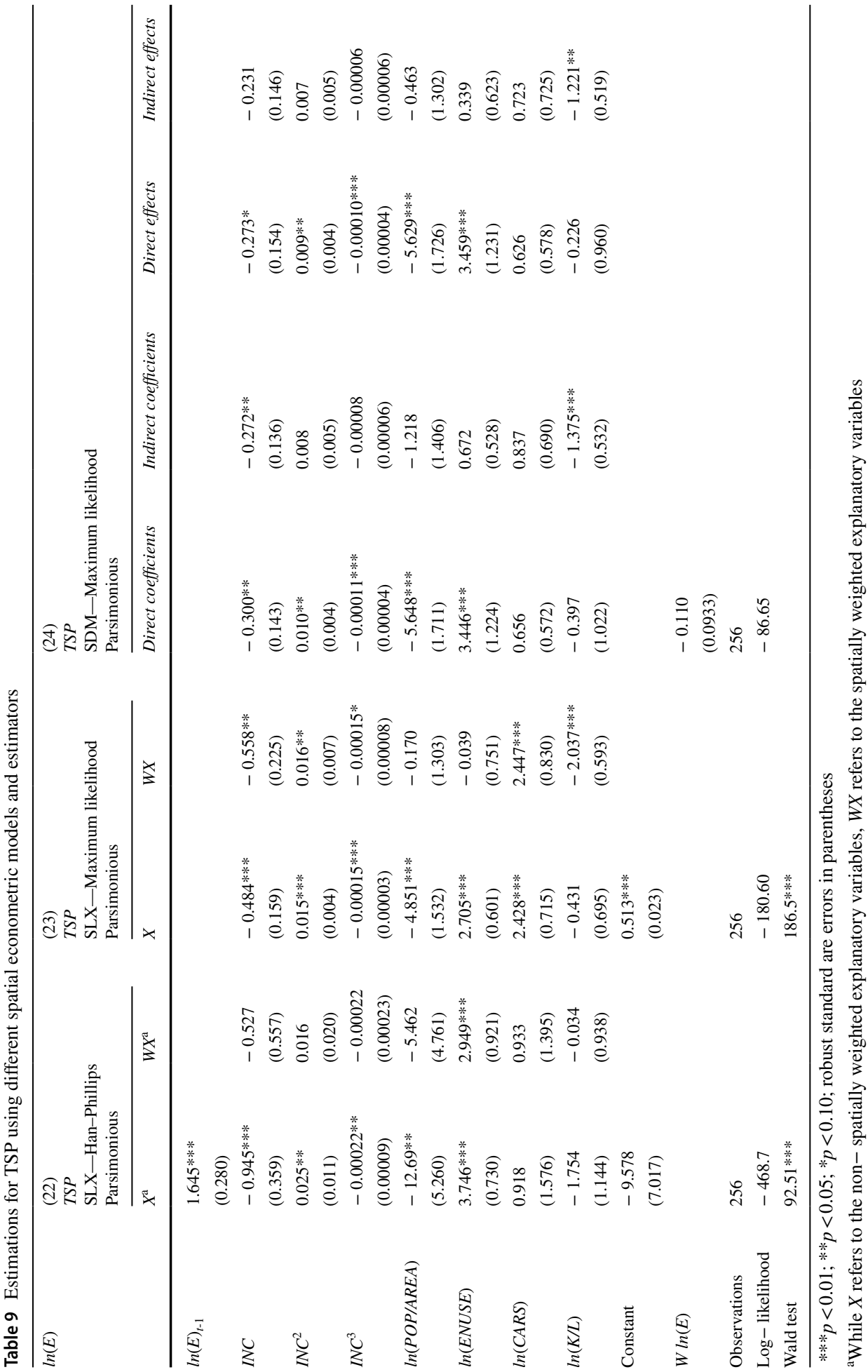




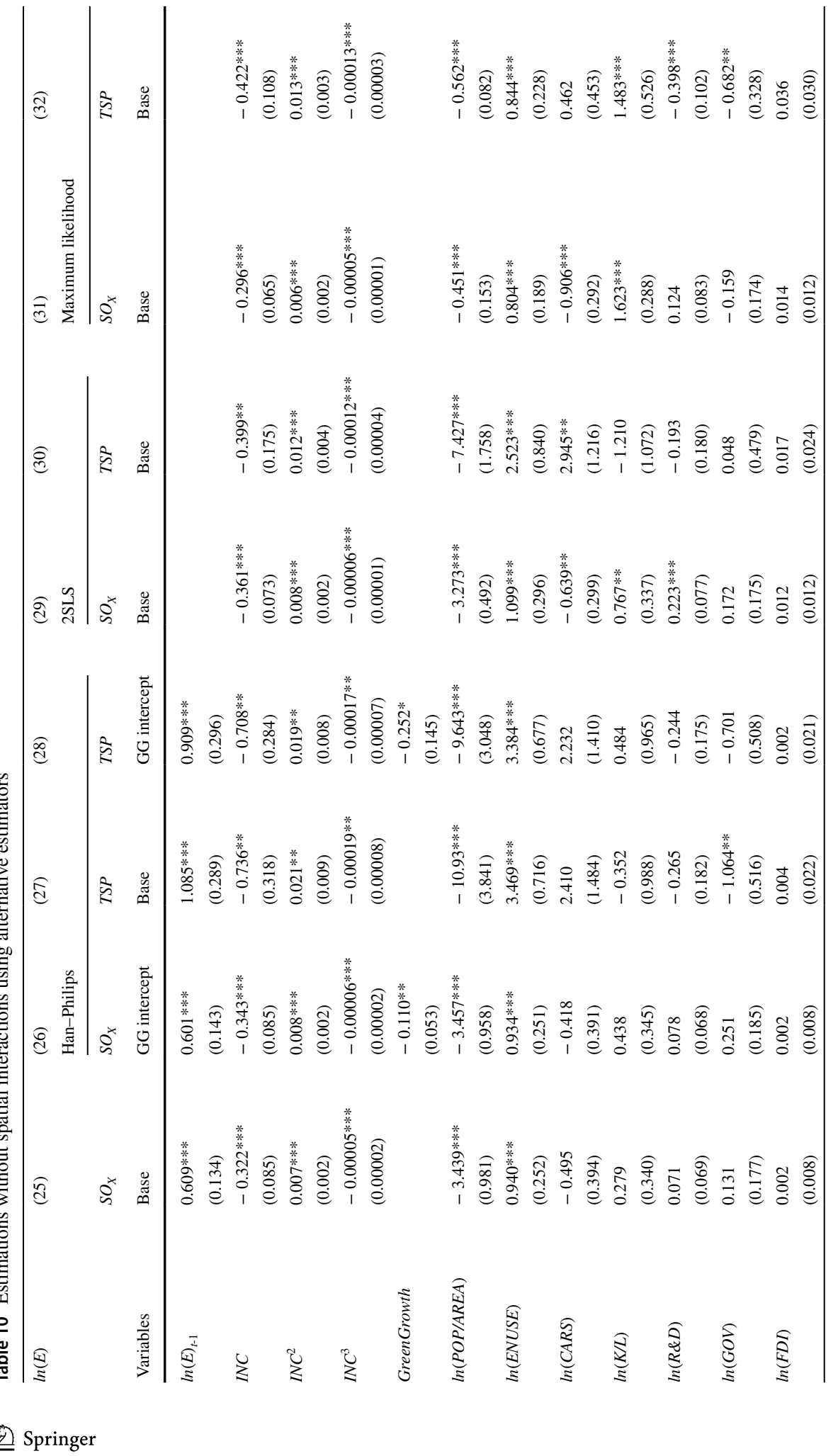




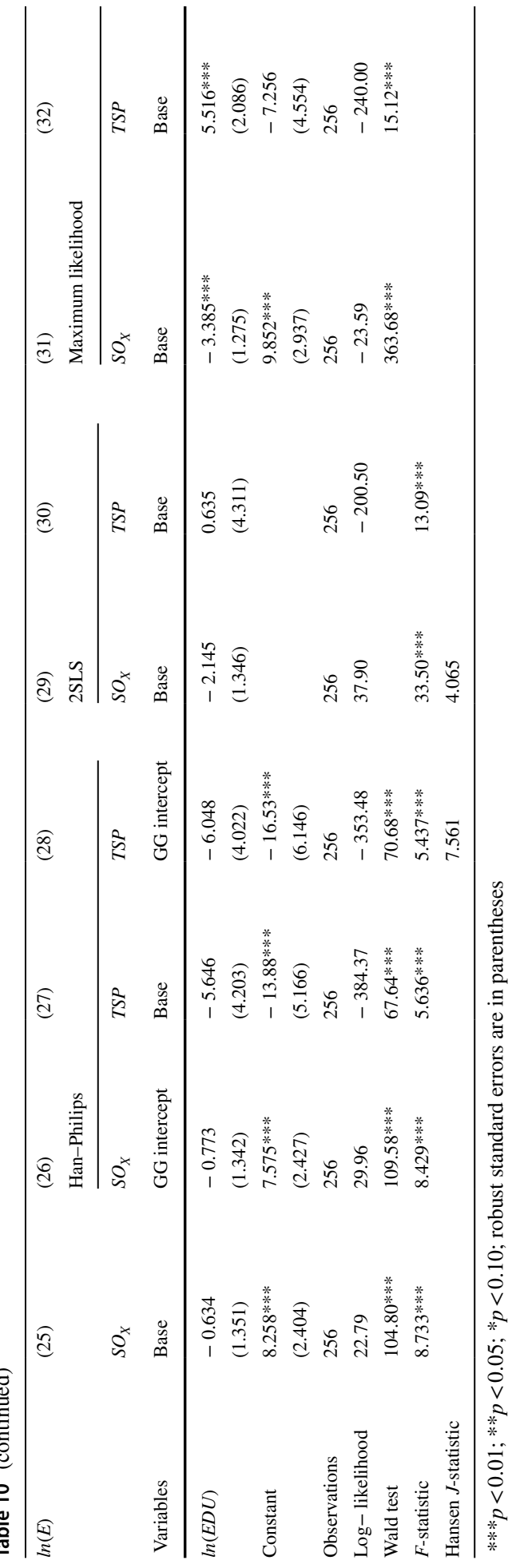




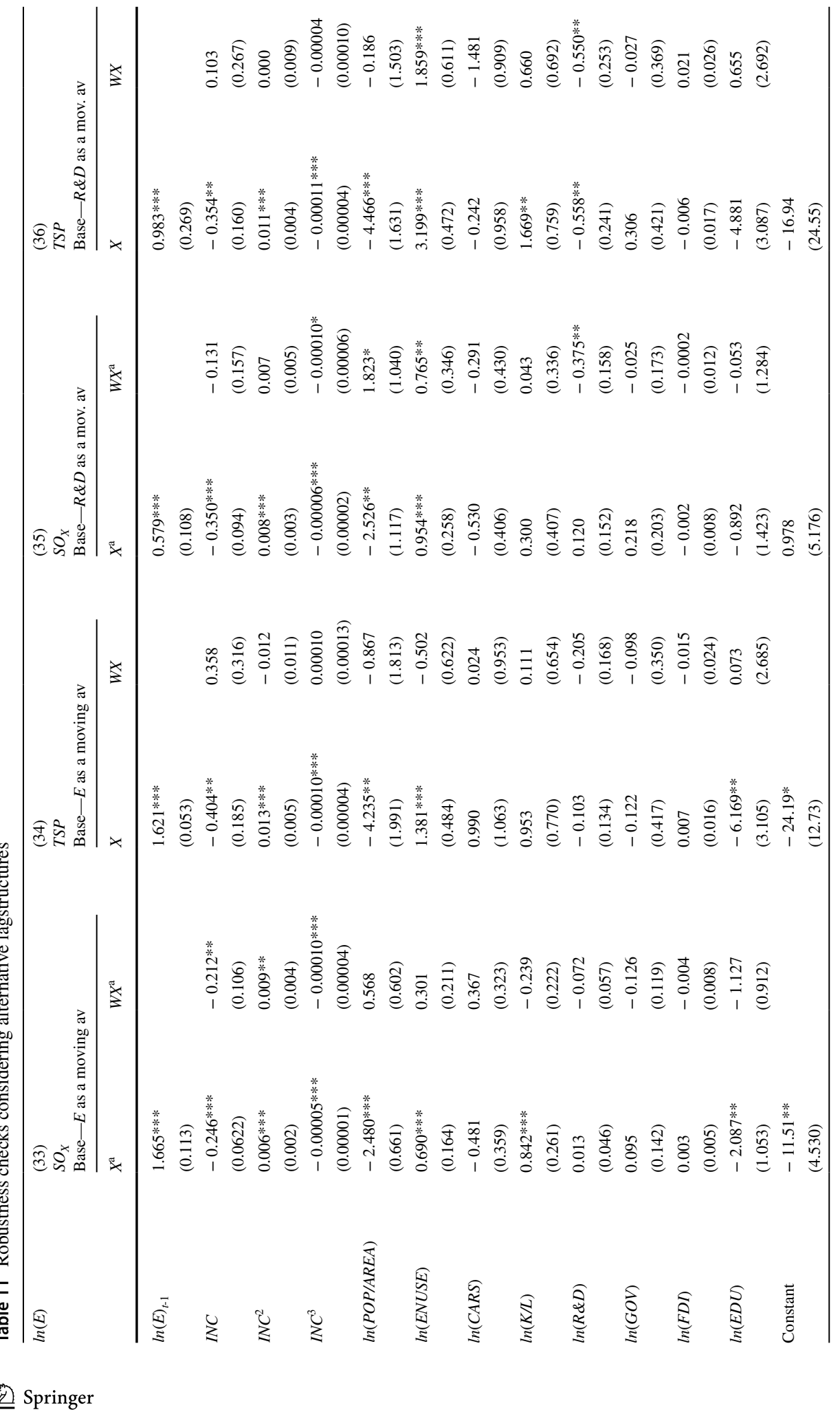




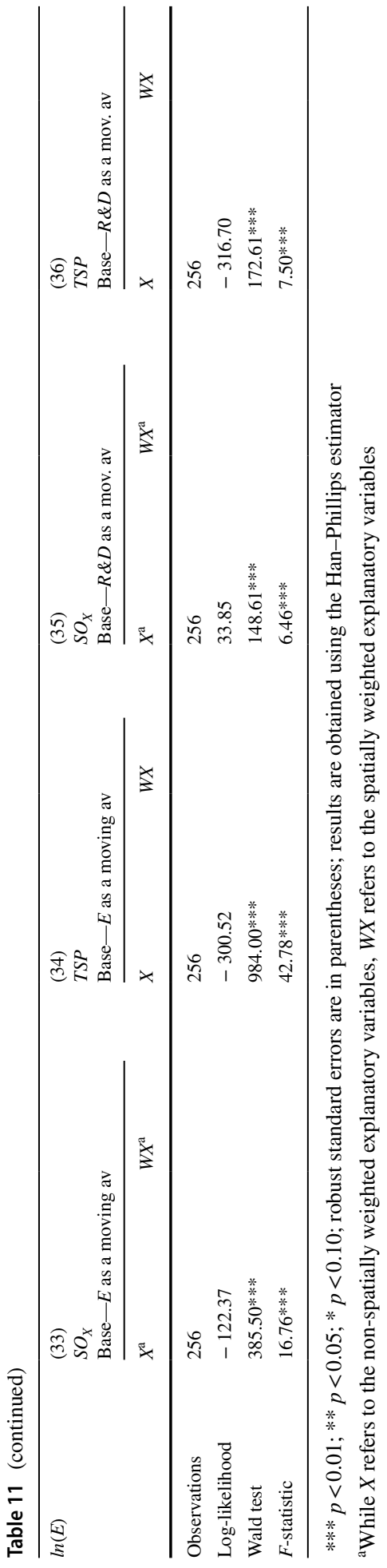


Table 12 Robustness checks 1st vs. 2nd Five-Year Plan for Green Growth and use of data until 2014 only

\begin{tabular}{|c|c|c|c|c|c|c|}
\hline \multirow[t]{2}{*}{$\overline{\ln (E)}$} & \multicolumn{2}{|l|}{$\begin{array}{l}(37) \\
S O_{X} \\
\text { GG intercept }\end{array}$} & \multicolumn{2}{|l|}{$\begin{array}{l}(38) \\
\text { TSP } \\
\text { GG intercept }\end{array}$} & \multicolumn{2}{|c|}{$\begin{array}{l}(39) \\
\text { TSP } \\
\text { Base_-Data until } 2014\end{array}$} \\
\hline & $X^{\mathrm{a}}$ & $W X^{\mathrm{a}}$ & $X$ & $W X$ & $X$ & $W X$ \\
\hline $\ln (E)_{t-1}$ & $\begin{array}{l}0.705^{* * *} \\
(0.090)\end{array}$ & & $\begin{array}{l}-0.639 * * \\
(0.281)\end{array}$ & & $\begin{array}{l}1.115^{* * *} \\
(0.088)\end{array}$ & \\
\hline$I N C$ & $\begin{array}{l}-0.392 * * * \\
(0.099)\end{array}$ & $\begin{array}{l}-0.211 \\
(0.180)\end{array}$ & $\begin{array}{l}-0.193 \\
(0.142)\end{array}$ & $\begin{array}{l}0.124 \\
(0.208)\end{array}$ & $\begin{array}{l}-0.433 * \\
(0.236)\end{array}$ & $\begin{array}{l}-0.021 \\
(0.353)\end{array}$ \\
\hline$I N C^{2}$ & $\begin{array}{l}0.009 * * * \\
(0.003)\end{array}$ & $\begin{array}{l}0.008 \\
(0.006)\end{array}$ & $\begin{array}{l}0.007 * * \\
(0.004)\end{array}$ & $\begin{array}{l}-0.001 \\
(0.006)\end{array}$ & $\begin{array}{l}0.015 * * \\
(0.007)\end{array}$ & $\begin{array}{l}-0.003 \\
(0.012)\end{array}$ \\
\hline$I N C^{3}$ & $\begin{array}{l}-0.00007 * * * \\
(0.00002)\end{array}$ & $\begin{array}{l}-0.00009 \\
(0.00006)\end{array}$ & $\begin{array}{l}-0.00008^{* * * *} \\
(0.00003)\end{array}$ & $\begin{array}{l}-0.00002 \\
(0.00006)\end{array}$ & $\begin{array}{l}-0.00010^{* *} \\
(-0.00006)\end{array}$ & $\begin{array}{l}0.00007 \\
(0.00010)\end{array}$ \\
\hline GreenGrowth $_{2009-2013}$ & $\begin{array}{l}-0.052 \\
(0.072)\end{array}$ & $\begin{array}{l}-0.072 \\
(0.055)\end{array}$ & $\begin{array}{l}-0.034 \\
(0.141)\end{array}$ & $\begin{array}{l}-0.037 \\
(0.115)\end{array}$ & & \\
\hline GreenGrowth $_{\text {Since } 2014}$ & $\begin{array}{l}-0.274 * * * \\
(0.103)\end{array}$ & $\begin{array}{l}-0.116 \\
(0.078)\end{array}$ & $\begin{array}{l}0.707 * * * \\
(0.202)\end{array}$ & $\begin{array}{l}0.267 \\
(0.194)\end{array}$ & & \\
\hline $\ln (P O P / A R E A)$ & $\begin{array}{l}-3.047 * * \\
(1.323)\end{array}$ & $\begin{array}{l}0.971 \\
(1.242)\end{array}$ & $\begin{array}{l}-1.983 \\
(1.332)\end{array}$ & $\begin{array}{l}1.825 \\
(1.273)\end{array}$ & $\begin{array}{l}-8.294 * * \\
(3.513)\end{array}$ & $\begin{array}{l}-3.845 \\
(3.231)\end{array}$ \\
\hline $\ln (E N U S E)$ & $\begin{array}{l}0.836 * * * \\
(0.241)\end{array}$ & $\begin{array}{l}0.591 * \\
(0.327)\end{array}$ & $\begin{array}{l}3.351 * * * \\
(0.461)\end{array}$ & $\begin{array}{l}1.494 * * \\
(0.663)\end{array}$ & $\begin{array}{l}2.803 * * * \\
(0.468)\end{array}$ & $\begin{array}{l}1.063^{*} \\
(0.624)\end{array}$ \\
\hline $\ln (C A R S)$ & $\begin{array}{l}0.011 \\
(0.432)\end{array}$ & $\begin{array}{l}0.227 \\
(0.445)\end{array}$ & $\begin{array}{l}-0.160 \\
(0.683)\end{array}$ & $\begin{array}{l}-0.489 \\
(0.844)\end{array}$ & $\begin{array}{l}0.612 \\
(1.027)\end{array}$ & $\begin{array}{l}0.732 \\
(0.952)\end{array}$ \\
\hline $\ln (K / L)$ & $\begin{array}{l}0.296 \\
(0.385)\end{array}$ & $\begin{array}{l}-0.361 \\
(0.321)\end{array}$ & $\begin{array}{l}2.232 * * * \\
(0.711)\end{array}$ & $\begin{array}{l}0.567 \\
(0.806)\end{array}$ & $\begin{array}{l}-0.979 \\
(0.765)\end{array}$ & $\begin{array}{l}0.956 \\
(0.655)\end{array}$ \\
\hline $\ln (R \& D)$ & $\begin{array}{l}0.059 \\
(0.064)\end{array}$ & $\begin{array}{l}0.036 \\
(0.082)\end{array}$ & $\begin{array}{l}-0.557 * * * \\
(0.190)\end{array}$ & $\begin{array}{l}-0.450 * * \\
(0.225)\end{array}$ & $\begin{array}{l}-0.106 \\
(0.118)\end{array}$ & $\begin{array}{l}0.0249 \\
(0.151)\end{array}$ \\
\hline $\ln (G O V)$ & $\begin{array}{l}0.196 \\
(0.202)\end{array}$ & $\begin{array}{l}0.004 \\
(0.168)\end{array}$ & $\begin{array}{l}0.398 \\
(0.424)\end{array}$ & $\begin{array}{l}-0.532 \\
(0.414)\end{array}$ & $\begin{array}{l}-0.202 \\
(0.384)\end{array}$ & $\begin{array}{l}0.0725 \\
(0.317)\end{array}$ \\
\hline $\ln (F D I)$ & $\begin{array}{l}0.001 \\
(0.007)\end{array}$ & $\begin{array}{l}-0.001 \\
(0.011)\end{array}$ & $\begin{array}{l}0.009 \\
(0.026)\end{array}$ & $\begin{array}{l}0.017 \\
(0.042)\end{array}$ & $\begin{array}{l}0.004 \\
(0.014)\end{array}$ & $\begin{array}{l}0.0274 \\
(0.0208)\end{array}$ \\
\hline $\ln (E D U)$ & $\begin{array}{l}0.482 \\
(1.366)\end{array}$ & $\begin{array}{l}-0.458 \\
(1.225)\end{array}$ & $\begin{array}{l}-6.553^{* *} \\
(2.625)\end{array}$ & $\begin{array}{l}-1.875 \\
(2.529)\end{array}$ & $\begin{array}{l}-0.930 \\
(2.961)\end{array}$ & $\begin{array}{l}-0.767 \\
(2.462)\end{array}$ \\
\hline Constant & $\begin{array}{l}0.993 \\
(3.965)\end{array}$ & & $\begin{array}{l}-21.23 \\
(26.37)\end{array}$ & & $\begin{array}{l}-5.881 \\
(4.122)\end{array}$ & \\
\hline Observations & 256 & & 256 & & 240 & \\
\hline Log-likelihood & 34.34 & & -234.82 & & -203.67 & \\
\hline Wald test & $176.45^{* * *}$ & & $393.86^{* * *}$ & & $216.73^{* * *} *$ & \\
\hline$F$-statistic & $6.54 * * *$ & & $14.59 * * *$ & & $9.42 * * *$ & \\
\hline
\end{tabular}

$* * * p<0.01 ; * * p<0.05 ; * p<0.10$; robust standard errors are in parentheses; results are obtained using the Han-Phillips estimator

${ }^{a}$ While $X$ refers to the non-spatially weighted explanatory variables, $W X$ refers to the spatially weighted explanatory variables 


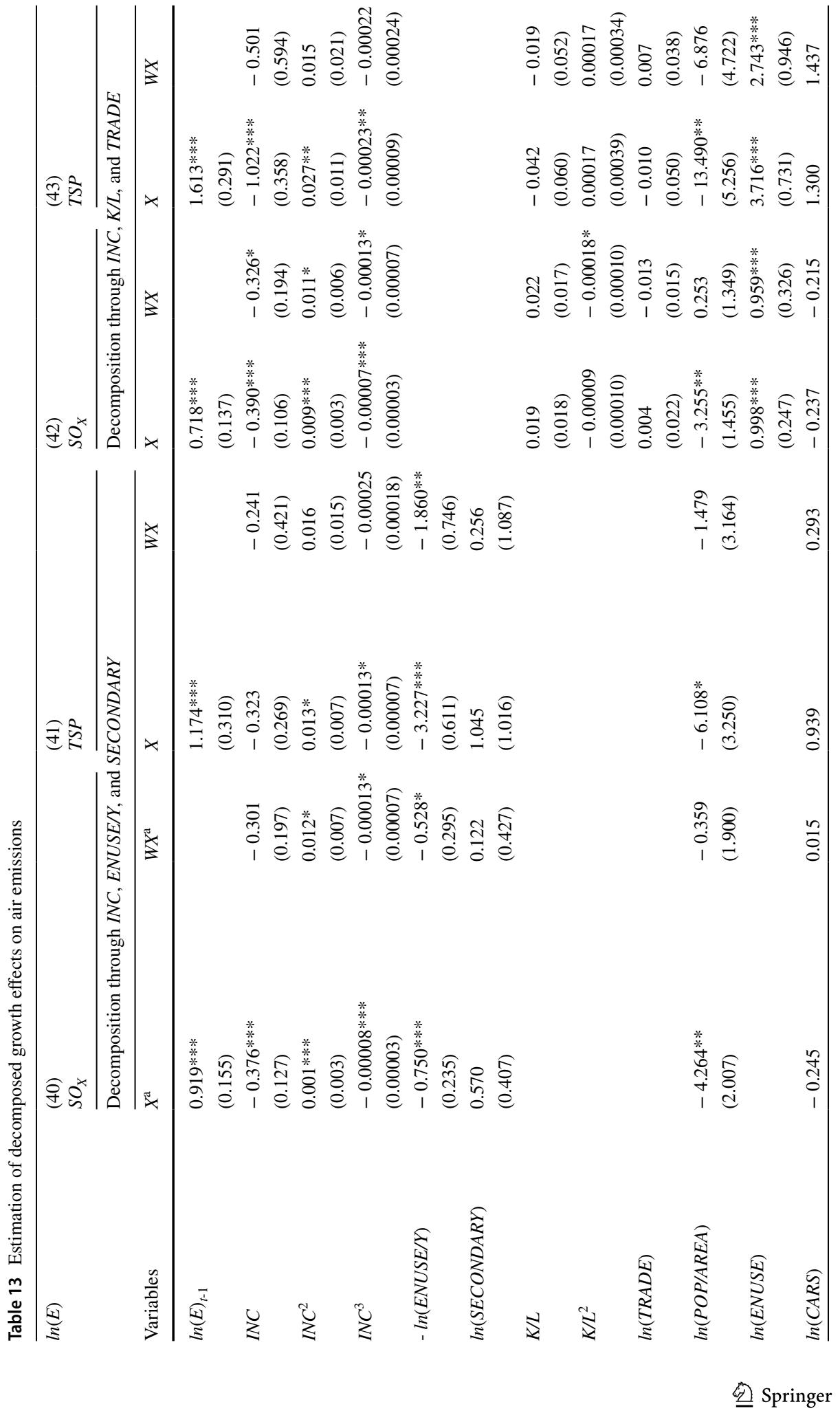




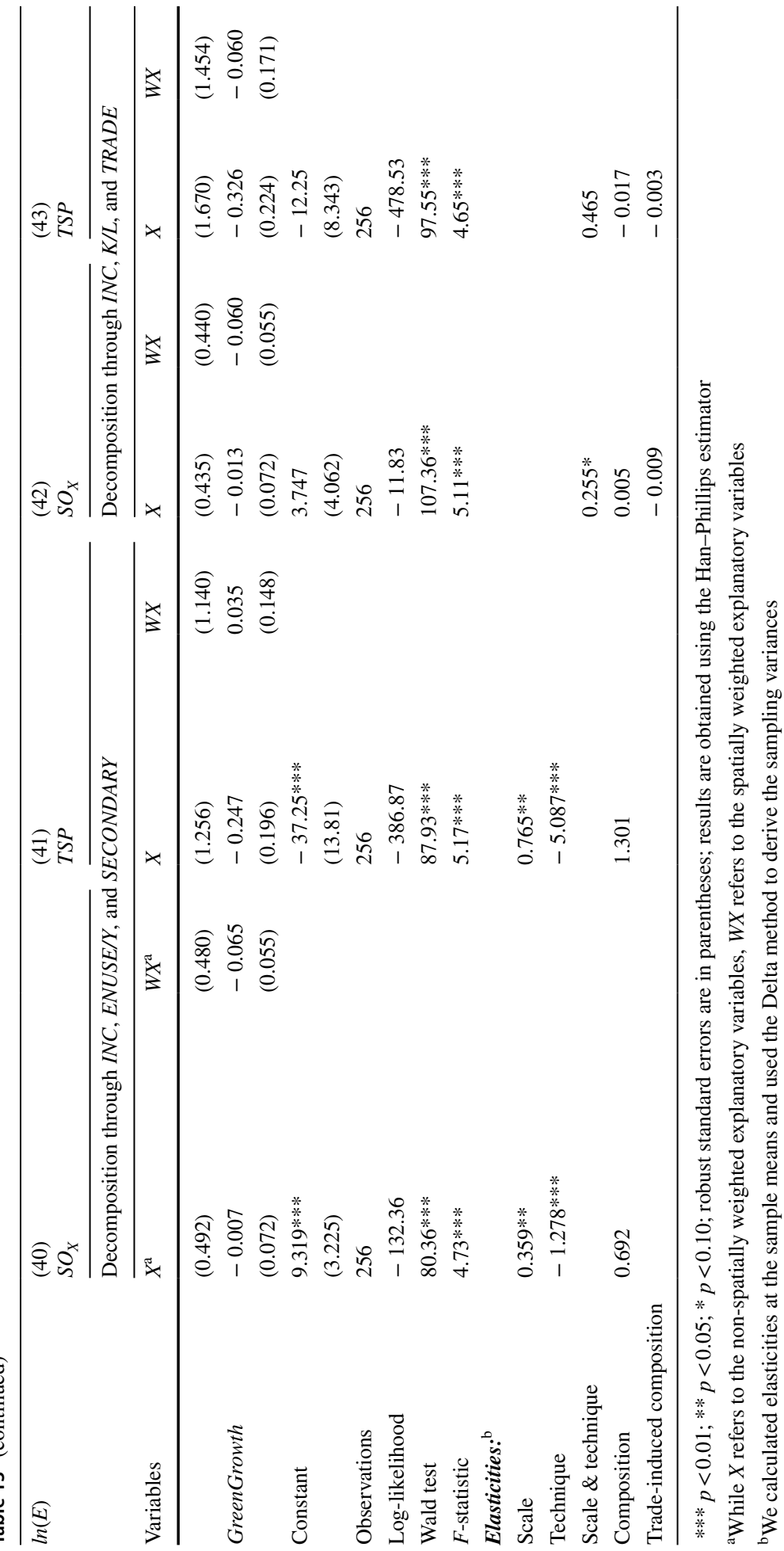


Funding Open Access funding enabled and organized by Projekt DEAL.

Open Access This article is licensed under a Creative Commons Attribution 4.0 International License, which permits use, sharing, adaptation, distribution and reproduction in any medium or format, as long as you give appropriate credit to the original author(s) and the source, provide a link to the Creative Commons licence, and indicate if changes were made. The images or other third party material in this article are included in the article's Creative Commons licence, unless indicated otherwise in a credit line to the material. If material is not included in the article's Creative Commons licence and your intended use is not permitted by statutory regulation or exceeds the permitted use, you will need to obtain permission directly from the copyright holder. To view a copy of this licence, visit http://creativecommons.org/licenses/by/4.0/.

\section{References}

Aden J, Kyu-Hong A, Rock MT (1999) What is driving the pollution abatement expenditure behavior of manufacturing plants in Korea? World Dev 27(7):1203-1214

Althammer W, Hille E (2016) Measuring climate policy stringency: A shadow price approach. Int Tax Public Finan 23(4):607-639

Anderson TW, Hsiao C (1981) Estimation of dynamic models with error components. J Am Stat Assoc 76(3):598-606

Andreoni J, Levinson A (2001) The simple analytics of the environmental Kuznets curve. J Public Econ 80(2):269-286

Antweiler W, Copeland BR, Taylor MS (2001) Is free trade good for the environment? Am Econ Rev 91(4):877-908

Arellano M, Bond S (1991) Some tests of specification for panel data: Monte Carlo evidence and an application to employment equations. Rev Econ Stud 58(2):277-297

Auffhammer M, Carson RT (2008) Forecasting the path of China's $\mathrm{CO}_{2}$ emissions using province-level information. J Environ Econ Manag 55(3):229-247

Auffhammer M, Steinhauser R (2007) The future trajectory of US $\mathrm{CO}_{2}$ emissions: the role of state vs aggregate information. J Reg Sci 47(1):47-61

Baek J, Kim HS (2013) Is economic growth good or bad for the environment? Empirical Evidence from Korea Energy Econ 36(3):744-749

Balado-Naves R, Baños-Pino JF, Mayor M (2018) Do countries influence neighbouring pollution? A spatial analysis of the EKC for $\mathrm{CO}_{2}$ emissions. Energy Policy 123(1):266-279

Balsalobre-Lorente D, Shahbaz M, Roubaud D, Farhani S (2018) How economic growth, renewable electricity and natural resources contribute to $\mathrm{CO}_{2}$ emissions? Energy Policy 113(1):356-367

Barro RJ, Lee JW (2013) A new data set of educational attainment in the world, 1950-2010. J Dev Econ 104(1):184-198

Brock WA, Taylor MS (2010) The Green Solow model. J Econ Growth 15(2):127-153

Brock WA, Taylor MS (2005) Chapter 28 - Economic Growth and the Environment: A Review of Theory and Empirics. In: Aghion P, Durlauf SN (eds) Handbook of Economic Growth, vol 1B, Elsevier, pp 1749-1821

Brunel C, Levinson A (2016) Measuring the stringency of environmental regulations. Rev Environ Econ Policy 10(1):47-67

Burnett JW, Bergstrom JC, Dorfman JH (2013) A spatial panel data approach to estimating US state-level energy emissions. Energy Econ 40(11):396-404

Carson RT (2010) The environmental Kuznets curve: Seeking empirical regularity and theoretical structure. Rev Environ Econ Policy 4(1):3-23

Cherniwchan J (2012) Economic growth, industrialization, and the environment. Resour Energy Econ 34(4):442-467

Choi J, Hearne R, Lee K, Roberts D (2015) The relation between water pollution and economic growth using the environmental Kuznets curve: A case study in South Korea. Water Int 40(3):499-512

Choi E, Heshmati A, Cho Y (2011) An empirical study of the relationships between $\mathrm{CO}_{2}$ emissions, economic growth and openness. Korean J Environ Policy 10(4):3-37

Cleveland CJ, Costanza R, Hall CAS, Kaufmann R (1984) Energy and the US economy: A biophysical perspective. Science 225(4665):890-897

Cole MA, Elliot RJR (2003) Determining the trade-environment composition effect: the role of capital, labor and environmental regulations. J Environ Econ Manag 46(3):363-383

Cole MA, Elliott RJR, Okubo T, Zhou Y (2013) The carbon dioxide emissions of firms: a spatial analysis. J Environ Econ Manag 65(2):290-309 
Cole MA, Elliott RJR, Shimamoto K (2005) Industrial characteristics, environmental regulations and air pollution: an analysis of the UK manufacturing sector. J Environ Econ Manag 50(1):121-143

Dijkgraaf E, Vollebergh HR (2005) A test for parameter homogeneity in $\mathrm{CO}_{2}$ panel EKC estimations. Environ Resour Econ 32(2):229-239

Dinda S (2005) A theoretical basis for the environmental Kuznets curve. Ecol Econ 53(3):403-413

Ehrlich PR, Holdren JP (1971) Impact of population growth. Science 171(3977):1212-1217

Elhorst JP (2010) Applied spatial econometrics: Raising the bar. Spat Econ Anal 5(1):9-28

Elhorst JP (2017) Spatial panel data analysis. In: Shekhar S, Xiong H, Zhou X (eds) Encyclopedia of GIS. Springer, Cham, pp 2050-2058

Florax RJGM, Folmer H, Rey SJ (2003) Specification searches in spatial econometrics: the relevance of Hendry's methodology. Reg Sci Urban Econ 33(5):557-579

Frankel J, Rose A (2005) Is trade good or bad for the environment? Sorting out the causality. Rev Econ Stat 87(1):85-91

GGGI (2015) Korea's Green Growth Experience: Process, Outcomes and Lessons Learned. Global Green Growth Institute, Seoul

Google Maps (2020) Google Maps. https://www.google.com/maps/. Accessed March 32020

Grether JM, Mathys NA, de Melo J (2009) Scale, technique and composition effects in manufacturing $\mathrm{SO}_{2}$ emissions. Environ Resour Econ 43(2):257-274

Grossman GM, Krueger AB (1995) Economic growth and the environment. Q J Econ 110(2):353-377

Grossman GM, Krueger AB (1991) Environmental impacts of the North American Free Trade Agreement. NBER Working Paper No. 3914

Halleck Vega S, Elhorst JP (2015) The SLX Model J Reg Sci 55(3):339-363

Han C, Phillips PCB (2010) GMM estimation for dynamic panels with fixed effects and strong instruments at unity. Econom Theory 26(1):119-151

Hao Y, Liu Y, Weng J-H, Gao Y (2016) Does the Environmental Kuznets Curve for coal consumption in China exist? New evidence from spatial econometric analysis. Energy 114(1):1214-1223

Hayakawa K (2007) Small sample bias properties of the system GMM estimator in dynamic panel data models. Econ Lett 95(1):32-78

Hille E, Shahbaz M (2019) Sources of emission reductions: Market and policy-stringency effects. Energy Econ 78(1):29-43

Hille E, Shahbaz M, Moosa I (2019) The impact of FDI on regional air pollution in the Republic of Korea: a way ahead to achieve the green growth strategy? Energy Econ 81(1):308-326

Hille E, Lambernd B (2020) The role of innovation in reducing South Korea's energy intensity: Regionaldata evidence on various energy carriers. J Environ Manag 262(1):110293

ICCT (2020) South Korea air quality standards. International Council on Clean Transportation. https:// www.transportpolicy.net/standard/south-korea-air-quality-standards/. Accessed May 12020

Jiang L, Folmer H, Ji M (2014) The drivers of energy intensity in China: a spatial panel data approach. China Econ Rev 31(1):351-360

Jones RS, Yoo B (2012) Achieving the "low carbon, green growth" vision in Korea. OECD Economics Department Working Papers, No. 964, OECD Publishing

KEEI (Korea Energy Economics Institute, 2018) Yearbook of Regional Energy Statistics 2018. Released December 2018

KOSIS (Korean Statistical Information Service, 2020) Regional accounts. http://kosis.kr/. Accessed February 152020

KOTRA (Korean Trade-Investment Promotion Agency, 2017) Inward FDI into Korea distributed by provinces. Received March 232017

Kang YQ, Zhao T, Yang YY (2016) Environmental Kuznets curve for $\mathrm{CO}_{2}$ emissions in China: a spatial panel data approach. Ecol Indic 63(4):231-239

Kijima M, Nishide K, Ohyama A (2010) Economic models for the environmental Kuznets curve: A survey. J Econ Dyn Control 34(7):1187-1201

Kim SE, Kim H, Chae Y (2014) A new approach to measuring green growth: application to the OECD and Korea. Futures 63(11):37-48

Kim S, Lee K, Kiseok N (2010) The relationship between $\mathrm{CO}_{2}$ emissions and economic growth: The case of Korea with nonlinear evidence. Energy Policy 38(10):5938-5946

Lan J, Kakinaka M, Huang X (2012) Foreign direct investment, human capital and environmental pollution in China. Environ Resour Econ 51(2):255-275

LeSage J (2014) Spatial econometric panel data model specification: A Bayesian approach. Spat Stat 9(1):122-145

LeSage J, Pace RK (2009) Introduction to Spatial Econometrics. Chapman and Hall/CRC, Boca Raton 
Levinson A (2015) A direct estimate of the technique effect: Changes in the pollution intensity of US manufacturing, 1990-2008. J Assoc Environ Resour Econ 2(1):43-56

Lieb CM (2002) The environmental Kuznets curve and satiation: a simple static model. Environ Dev Econ 7(3):429-448

Lim HJ, Yoo SH, Kwak SJ (2009) Industrial $\mathrm{CO}_{2}$ emissions from energy use in Korea: A structural decomposition analysis. Energy Policy 37(2):686-698

Lopez RE, Yoon SW (2014) Pollution-income dynamics. Econ Lett 124(3):504-507

Maddison D (2006) Environmental Kuznets curves: A spatial econometric approach. J Environ Econ Manag 51(2):218-230

Managi S, Hibiki A, Tsurumi T (2009) Does trade openness improve environmental quality? J Environ Econ Manag 58(3):346-363

Mankiw NG, Romer D, Weil DN (1992) A contribution to the empirics of economic growth. Q J Econ 107(2):407-437

Mathews JA (2012) Green growth strategies: Korea's initiatives. Futures 44(8):761-769

McAusland C, Millimet DL (2013) Do national borders matter? Intranational trade, international trade, and the environment. J Environ Econ Manag 65(3):411-437

Meadows DH, Meadows DL, Randers J, Behrens WH (1972) The limits to growth: report: a report to the Club of Rome's project on the predicament of mankind. Universe Books, New York

Meng L, Huang B (2018) Shaping the relationship between economic development and carbon dioxide emissions at the local level: Evidence from spatial econometric models. Environ Resour Econ 71(1):127-156

NGII (2017) The National Atlas of Korea: Comprehensive Edition. National Geographic Information Institute, Ministry of Land Infrastructure and Transport, Sejong

NIER (National Institute of Environmental Research, 2020) National air pollutant emissions. http://airemiss. nier.go.kr. Accessed March 32020

Nasr AB, Gupta R, Sato JR (2015) Is there an environmental Kuznets curve for South Africa? A co-summability approach using a century of data. Energy Econ 52(A):136-141

OECD (2020) OECD.Stat. https://stats.oecd.org/. Accessed March 52020

Oh I, Wehrmeyer W, Mulugetta Y (2010) Decomposition analysis and mitigation strategies of $\mathrm{CO}_{2}$ emissions from energy consumption in South Korea. Energy Policy 38(1):364-377

Park J, Hong T (2013) Analysis of South Korea's economic growth, carbon dioxide emission, and energy consumption using the Markov switching model. Renew Sustain Energy Rev 18(2):543-551

Park S, Lee Y (2011) Regional model of EKC for air pollution: evidence from the Republic of Korea. Energy Policy 39(10):5840-5849

Pasten R, Figueroa E (2012) The environmental Kuznets curve: a survey of the theoretical literature. Int Rev Environ Resour Econ 6(3):195-224

Phillips PCB, Han C (2008) Gaussian inference in AR(1) times series with or without unit root. Econom Theory 24(3):631-650

Popp D (2016) Economic analysis of scientific publications and implications for energy research and development. Nat Energy 1(1):16020

Rios V, Gianmoena L (2018) Convergence in $\mathrm{CO}_{2}$ emissions: a spatial economic analysis with cross-country interactions. Energy Econ 75(1):222-238

Rupasingha A, Goetz SJ, Debertin DL, Pagoulatos A (2004) The environmental Kuznets curve for US counties: a spatial econometric analysis with extensions. Pap Reg Sci 83(2):407-424

Sapkota P, Bastola U (2017) Foreign direct investment, income, and environmental pollution in developing countries: Panel data analysis of Latin America. Energy Econ 64(1):206-212

Selden TM, Song D (1994) Environmental quality and development: Is there a Kuznets curve for air pollution emissions? J Environ Econ Manag 27(2):147-162

Shafik N (1994) Economic development and environmental quality: An econometric analysis. Oxf Econ Pap 46(1):757-773

Shahbaz M, Sinha A (2019) Environmental Kuznets curve for $\mathrm{CO}_{2}$ emissions: A literature survey. J Econ Stud 46(1):106-168

Sharma AP, Kim K-H, Ahn J-W, Shon Z-H, Sohn J-R, Lee J-H, Ma C-J, Brown RJC (2014) Ambient particulate matter (PM10) concentrations in major urban areas of Korea during 1996-2010. Atmos Pollut Res 5(1):161-169

Smulders S, Bretschger L, Egli H (2011) Economic growth and the diffusion of clean technologies: explaining environmental Kuznets curves. Environ Resour Econ 49(1):79-99

Sonnenschein J, Mundaca L (2016) Decarbonization under green growth strategies? The case of South Korea. J Clean Prod 123(6):180-193

Stern DI (2017) The environmental Kuznets curve after 25 years. J Bioeconomics 19(1):7-28 
Yang CH, Tseng YH, Chen CP (2012) Environmental regulations, induced R\&D, and productivity: evidence from Taiwan's manufacturing industries. Resour Energy Econ 34(4):514-532

Yu H (2012) The influential factors of China's regional energy intensity and its spatial linkages: 1988-2007. Energy Policy 45(6):583-593

Zhao X, Burnett JW, Fletcher JJ (2014) Spatial analysis of China province-level $\mathrm{CO}_{2}$ emission intensity. Renew Sustain Energy Rev 33(5):1-10

Zugravu-Soilita N (2017) How does foreign direct investment affect pollution? Toward a better understanding of the direct and conditional effects. Environ Resour Econ 66(2):293-338

Publisher's Note Springer Nature remains neutral with regard to jurisdictional claims in published maps and institutional affiliations. 